\title{
Functionalised Carbon Nanotubes Enhance Brain Delivery of Amyloid-Targeting Pittsburgh Compound B (PiB)-Derived Ligands
}

\author{
Pedro Miguel Costa ${ }^{1}$, Julie Tzu-Wen Wang1\#, Jean-François Morfin²\#, Tamanna Khanum² ${ }^{1}$, Wan To ${ }^{1}$, Jane \\ Sosabowski³, Eva Tóth ${ }^{\circledR}$, Khuloud T Al-Jamal ${ }^{\circledR}$ \\ 1. School of Cancer \& Pharmaceutical Sciences, Faculty of Life Sciences \& Medicine, King's College London, SE1 9NH, London, United Kingdom. \\ 2. Centre de Biophysique Moléculaire, UPR 4301, CNRS, Université d'Orléans, Rue Charles Sadron CS 80054, 45071, Orléans Cedex 2, France. \\ 3. Centre for Molecular Oncology, Bart's Cancer Institute, Queen Mary University of London, London, EC1M 6BQ, United Kingdom. \\ \# Authors share equal contribution \\ $\bowtie$ Corresponding author: eva.jakabtoth@cnrs.fr; khuloud.al-jamal@kcl.ac.uk
}

(C) Ivyspring International Publisher. This is an open access article distributed under the terms of the Creative Commons Attribution (CC BY-NC) license (https://creativecommons.org/licenses/by-nc/4.0/). See http://ivyspring.com/terms for full terms and conditions.

Received: 2017.10.12; Accepted: 2017.12.21; Published: 2018.02.15

\begin{abstract}
Alzheimer's disease $(A D)$ is a neurodegenerative disorder characterised by brain accumulation of toxic protein aggregates, including extracellular amyloid beta $(A \beta)$ plaques, inflammation, neuronal death and progressive cognitive dysfunction. Current diagnostic modalities, based on cognitive tests, fail to detect early $A D$ onset, thus emphasising the need to develop improved methods for pre-symptomatic disease detection.

Building on the properties of the Pittsburgh Compound B (PiB), an A use as positron emission tomography (PET) imaging agent, and aiming at using a more clinically available modality (like magnetic ressonance imaging, MRI), PiB derivatives have been conjugated to the macrocyclic chelator 1,4,7-tris(carboxymethyl)-1,4,7,10-tetraazacyclododecane (DO3A) monoamide. However, these derivatives do not readily cross the highly selective blood-brain barrier (BBB). Taking advantage of the capacity of functionalised carbon nanotubes ( $f$-CNTs) to cross biological barriers, including the $\mathrm{BBB}$, this manuscript reports on the conjugation of two PiB derivative $\mathrm{Gd}^{3+}$ complexes - $\mathrm{Gd}\left(\mathrm{L}_{2}\right)$ and $\mathrm{Gd}\left(\mathrm{L}_{3}\right)$ - to multi-walled $f$-CNTs (f-MWNTs) and assessment of their in vivo biodistribution and brain uptake. It is shown that $G d\left(L_{2}\right)$ and $G d\left(L_{3}\right)$ can be efficiently loaded onto different $f-M W N T s$, with significant improvement in brain accumulation of the conjugates compared to the free metal complexes.

Overall, this study demonstrates that $f$-MWNTs have potential to be used as carriers in theranostic applications involving brain delivery of BBB impermeable compounds.
\end{abstract}

Key words: Alzheimer's disease, A $\beta$ plaques, Pittsburgh Compound B, carbon nanotubes (CNTs), brain delivery

\section{Introduction}

Alzheimer's disease (AD) is a chronic neurodegenerative disorder affecting mostly the elderly population, characterised by brain accumulation of protein aggregates, including intracellular neurofibrillary tangles (formed of hyperphosphorylated tau protein) and extracellular senile plaques (formed of fibrillary amyloid beta $(\mathrm{A} \beta)$ peptides) [1]. Accumulation of misfolded protein, in association with deficient immune response (chronic activation and disturbance of microglial clearance functions) [2], is the main cause of neuronal death and associated cognitive dysfunction seen in AD patients [3]. Current diagnostic methods, based on cognitive tests, fail to detect early $\mathrm{AD}$ onset, while imaging 
modalities such as magnetic resonance imaging (MRI) can detect structural brain changes only at advanced stages of disease [4]. In recent years substantial resources have also been invested in the identification of biomarkers in cerebrospinal fluid (CSF), to identify a prodromal $\mathrm{AD}$ signature that could improve diagnosis [5]. There is therefore a clear need to develop non-invasive neuroimaging-based methods for precise and early detection of this disease.

Accurate in vivo imaging of $A \beta$ plaque deposition could be a fundamental step towards effective early diagnosis of $\mathrm{AD}$, as well as an important tool for monitoring of therapy efficacy and disease progression. Over the last decade, several small organic $A \beta$-targeting compounds have been identified, including benzothiazoles, stilbenes [6] and thioflavin $\mathrm{T}$ derivatives, such as the Pittsburgh Compound B (PiB) [7]. Despite good blood-brain barrier (BBB)-crossing ability, high in vivo binding affinity towards $A \beta$ and suitable properties for usage in positron emission tomography (PET), their clinical application is limited by short radioisotope lifetime, use of ionising radiation and low spatial resolution. In contrast to nuclear imaging modalities, MRI allows non-invasive imaging of brain structures with superior spatial resolution, avoiding patient exposure to ionising radiation and at a smaller cost. MRI resolution can be further enhanced by paramagnetic contrast agents, including gadolinium $\left(\mathrm{Gd}^{3+}\right)$ chelates or iron oxide nanoparticles [8]. Given the high electronic spin and slow relaxation times, $\mathrm{Gd}^{3+}$ complexes are the most widely used MRI contrast materials [8]. Selenium-based nanoparticles have also been successfully tested for $A \beta$ binding and disruption, although their in vivo activity has yet to be demonstrated $[9,10]$.

Aiming at developing metal-based multimodal imaging probes for detection of $\mathrm{A} \beta$ plaques, $\mathrm{PiB}$ derivatives have been synthesised by conjugation to 1,4,7,10-tetraazacyclododecane-1,4,7-triacetic acid (DO3A) monoamide [11, 12], a non-ionic macrocyclic chelator that forms stable, neutral complexes with trivalent metal ions, including $\mathrm{Gd}^{3+}$ (for MRI) and Indium-111 $\left({ }^{111} \mathrm{In}^{3+}\right)$ (for single-photon emission computed tomography, SPECT). Moreover, the intrinsic fluorescence of the PiB moiety [13] could potentially allow for high-resolution optical microscopy tracing of the imaging probe. While ex vivo staining of human $\mathrm{AD}$ brain tissue showed that these derivatives selectively target $A \beta$ plaques [11], their clinical application is limited by the reduced ability to cross the BBB [11, 12]. The BBB permeability of a compound is directly influenced by three main physico-chemical and physiological parameters: (i) lipophilicity, represented by the water/octanol partition coefficient ( $\log P_{\text {oct/water }}$ ), (ii) molecular weight and (iii) plasma pharmacokinetics [14]. In previous studies, it was shown that the lipophilicity of the $\mathrm{PiB}$ derivatives $\mathrm{Gd}\left(\mathrm{L}_{1}\right)$ and $\mathrm{Gd}\left(\mathrm{L}_{2}\right)\left(\log P_{\text {oct/water }}=\right.$ -0.15 and 0.03 , respectively) $[11,12]$ is reduced compared to the highly lipophilic PiB $\left(\log P_{\text {oct} / \text { water }}=\right.$ 1.23) and other compounds with optimal BBB permeation ( $\left.\log P_{\text {oct/water }} 2\right)$ [15]. Biodistribution experiments in healthy adult Swiss mice using an ${ }^{111}$ In-labelled analogue of $\mathrm{Gd}\left(\mathrm{L}_{1}\right)$ have also revealed moderate $\mathrm{BBB}$ penetration $(0.36 \%$ of the injected dose per gram of tissue in the cortex at 2 min after injection) [11].

To improve brain delivery, impermeable compounds could be conjugated to nanocarriers capable of translocating across the BBB - either per se or upon targeting to transporters expressed in the brain vasculature - and reaching the desired regions in the brain [16]. In this regard, carbon nanotubes (CNTs) display unique physico-chemical properties suitable for use in nanomedicine applications, including large surface area (allowing conjugation of therapeutic and imaging molecules), electrochemical stability and a high aspect ratio [17-19]. Further surface modification/functionalisation with hydrophilic molecules, polymers or other biocompatible molecules can enhance CNT water dispersibility, reduce toxicity and improve target cell/tissue delivery [20-23]. Importantly, the ability of functionalised CNTs ( $f$-CNTs) to cross biological barriers by energy-dependent (transcytosis) and independent (passive) mechanisms, as well as intrinsic optical and thermal properties, constitutes a major CNT advantage for brain-targeted theranostic applications, compared to other nanocarriers [24]. Previous in vitro and in vivo proof-of-concept studies from our group demonstrated that functionalised multi-walled carbon nanotubes ( $f$-MWNTs) cross an intact BBB [25-27]. Functional degradation, including loss of cylindrical structure, was also reported for stereotactically-administered $f$-MWNTs in mouse brain, most probably mediated by peroxidases and other degradative enzymes released by microglia [28].

Aiming at improving brain delivery of optimised $\mathrm{PiB}$ derivatives, in this study two different complexes - $\mathrm{Gd}\left(\mathrm{L}_{2}\right)$ and $\mathrm{Gd}\left(\mathrm{L}_{3}\right)$ (Fig. 1) - were non-covalently conjugated to $f$-MWNTs. MWNT characterisation was performed using thermogravimetric analysis (TGA) and Kaiser test, while conjugation was evaluated using inductively coupled plasma mass spectrometry (ICP-MS) and fluorimetry. Finally, the ligands $\mathrm{L}_{2} / \mathrm{L}_{3}$ were conjugated to $f$-MWNTs and radiolabelled with ${ }^{111} \mathrm{In}$, thus allowing quantification of in vivo biodistribution and brain uptake by SPECT/CT and $\gamma$-scintigraphy. 
<smiles>COc1ccc2nc(-c3ccc(NC(=O)CN4CCN(CC(=O)O)CCN(CC(=O)O)CCN(CC(=O)O)CC4)cc3)sc2c1</smiles>

$\mathbf{L}_{1}$
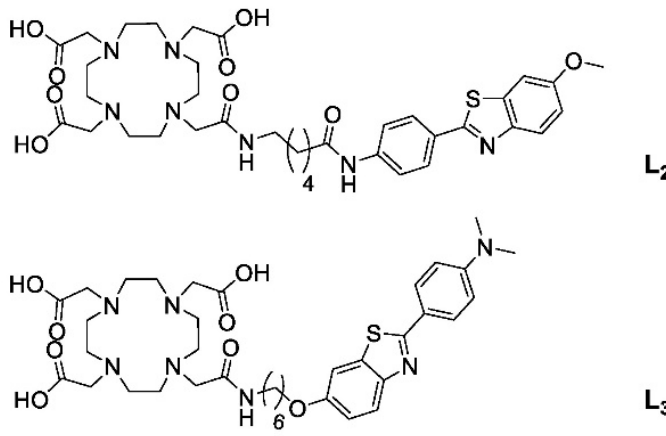

$\mathrm{L}_{3}$

Figure 1. Structure of ligands.

\section{Experimental Section}

\section{Reagents and solutions}

Pristine MWNTs (NC3100, Batch \#120710, > 95\% wt. purity, average dimensions of $1.5 \mu \mathrm{m}$ (length) and $9.5 \mathrm{~nm}$ (diameter)), were purchased from Nanocyl SA (Sambreville, Belgium). Chemicals (listed in Supplementary Materials) were purchased from Fisher Scientific, Sigma-Aldrich, Alfa Aesar, TCI Europe and CheMatech, and were used without further purification. Analytical grade solvents were used and were not purified further unless specified. Isopore hydrophilic and hydrophobic membrane filters $(0.2 \mu \mathrm{m}$ pore size) were purchased from Merck Millipore (Watford, UK). The radioactive probe ${ }^{111} \mathrm{InCl}_{3}$ as an aqueous solution in $0.5 \mathrm{M} \mathrm{HCl}$ was purchased from Mallinckrodt Pharmaceuticals (The Netherlands) which is used directly without further purification. Instant thin layer chromatography paper impregnated with silica gel (iTLC-SG) was obtained from Agilent Technologies (UK). Fetal bovine serum was purchased from First Link Ltd (UK). All reagents and analytical grade solvents were used without further purification, unless specified. Other materials and equipment used for chemical synthesis are listed in Supplementary Material.

\section{Synthesis of $\mathbf{G d}\left(L_{2}\right)$ and $\mathbf{G d}\left(L_{3}\right)$}

$\mathrm{Gd}\left(\mathrm{L}_{3}\right)$ was synthesised as shown in Scheme 1. The synthesis of $\mathrm{Gd}\left(\mathrm{L}_{2}\right)$ has been previously reported [12]. For the synthesis of $\mathrm{Gd}\left(\mathrm{L}_{3}\right)$, reactions were monitored by thin-layer chromatography (TLC) on Kieselgel 60 F254 (Merck) on an aluminium support, with detection by examination under UV light (254 $\mathrm{nm}$ ), by spraying with ninhydrin, and by coloration of the complex with Dragendorff solutions. Polar affinity chromatography was performed with silica gel (SigmaAldrich). ${ }^{1} \mathrm{H}$ and ${ }^{13} \mathrm{C}$ NMR spectra were recorded on a Bruker Avance Spectrometer using a $5 \mathrm{~mm}$ BBFO probe at 599.903 and $150.860 \mathrm{MHz}$ for ${ }^{1} \mathrm{H}$ and ${ }^{13} \mathrm{C}$, respectively. High Resolution Mass spectrometry (HRMS) was performed at the Centre de Biophysique Moléculaire du CNRS in Orléans, France.

\section{4-(6-methoxybenzo[d]thiazol-2-yl)-N,N-dimethylanili} ne: 2

In a round flask, [d]thiazol-2-yl)aniline 1 (500 mg, $1.95 \mathrm{mmol}$ ) and paraformaldehyde (600mg, $20 \mathrm{mmol}$ ) were dissolved in $50 \mathrm{ml}$ of acetic acid. After $1 \mathrm{~h}$ at room temperature, sodium cyanoborohydride $(400 \mathrm{mg}, 6.36$ mmol) was added and the solution was mixed overnight. The reaction was neutralised by adding ammonium hydroxide. A yellowish precipitate was formed, collected and washed with water to give, without further purifications, $538 \mathrm{mg} \quad(97 \%)$ of compound 2 .

${ }^{1} \mathrm{H} \quad \mathrm{NMR} \quad\left(\mathrm{CDCl}_{3}, 298 \mathrm{~K}\right.$, $599.902 \mathrm{MHz}): 3.05 \quad(\mathrm{~s}, \quad 6 \mathrm{H}$, $\left.\mathrm{N}-\left(\mathrm{CH}_{3}\right)_{2}\right) ; 3.88$ (s, $\left.3 \mathrm{H},-\mathrm{OCH}_{3}\right)$; $6.74\left(\mathrm{~d}, 3 \mathrm{~J}=8.9 \mathrm{~Hz}, 2 \mathrm{H}_{\mathrm{ar}}\right) ; 7.03(\mathrm{dd}$, $\left.{ }^{3} \mathrm{~J}=8.9 \mathrm{~Hz},{ }^{4} \mathrm{~J}=2.5 \mathrm{~Hz}, 1 \mathrm{H}_{\mathrm{ar}}\right) ; 7.32(\mathrm{~d}$,
Scheme 1. Synthesis of $\mathbf{G d}\left(\mathbf{L}_{3}\right)$. The reagents and conditions were as follows: a) paraformaldehyde, $\mathrm{NaCNBH}_{3}$ $\mathrm{AcOH}, \mathrm{RT}, 12 \mathrm{~h}, 97 \%$; b) $\mathrm{BBr}_{3}, \mathrm{CH}_{2} \mathrm{Cl}_{2}, 0^{\circ} \mathrm{C}$, 1h, 99\%; c) $\mathrm{N}$-(6-Bromohexyl)phthalimide, $\mathrm{K}_{2} \mathrm{CO}_{3}$, Acetone, reflux, $72 \mathrm{~h}$ $86 \%$; d) $\mathrm{NH}_{2} \mathrm{NH}_{2}$, reflux, $2 \mathrm{~h}, 99 \%$; e) Chloroacetyl Chloride, $\mathrm{NEt}_{3}, \mathrm{THF}, 0^{\circ} \mathrm{C}, 3 \mathrm{~h}, 83 \%$; f) DO3A-tBu, $\mathrm{K}_{2} \mathrm{CO}_{3}, \mathrm{CH}_{3} \mathrm{CN}$, reflux, 16h, 76\%; g) TFA, $\mathrm{CH}_{2} \mathrm{Cl}_{2}, \mathrm{RT}, 3 \mathrm{~h}, 82 \%$; h) $\mathrm{GdCl}_{3}$, $\mathrm{pH} 5,5,2 \mathrm{~h}$. 
$\left.{ }^{4} \mathrm{~J}=2.5 \mathrm{~Hz}, 1 \mathrm{H}_{\mathrm{ar}}\right) ; 7.86\left(\mathrm{~d},{ }^{3} \mathrm{~J}=8.9 \mathrm{~Hz}, 1 \mathrm{H}_{\mathrm{ar}}\right) ; 7.90\left(\mathrm{~d},{ }^{3} \mathrm{~J}=\right.$ $\left.8.9 \mathrm{~Hz}, 2 \mathrm{H}_{\mathrm{ar}}\right)$

${ }^{13} \mathrm{C}$ NMR $\left(\mathrm{CDCl}_{3}, 298 \mathrm{~K}, 150.86 \mathrm{MHz}\right): 42.4$ (2C, -N-( $\left.\left.\underline{\mathrm{CH}}_{3}\right)_{2}\right) ; 56.0\left(1 \mathrm{C},-\mathrm{OCCH}_{3}\right) ; 104.6\left(1 \mathrm{C}_{\mathrm{ar}}\right) ; 112.0\left(2 \mathrm{C}_{\mathrm{ar}}\right)$; $115.1\left(1 \mathrm{C}_{\mathrm{ar}}\right) ; 121.8\left(1 \mathrm{C}_{\mathrm{ar}}\right) ; 123.0\left(1 \mathrm{C}_{\mathrm{ar}}\right) ; 128.7\left(2 \mathrm{C}_{\mathrm{ar}}\right)$; 136.0 (1Car); $152.1\left(1 \mathrm{C}_{\mathrm{ar}}\right) ; 157.3\left(1 \mathrm{C}_{\mathrm{ar}}\right) ; 166.7\left(1 \mathrm{C}_{\mathrm{ar}}\right)$

\section{2-(4-(dimethylamino)phenyl)benzo[d]thiazol-6-ol: 3}

Compound 2 (500 mg, $1.76 \mathrm{mmol}$ ) was dissolved in $12 \mathrm{ml}$ of dichloromethane at $0^{\circ} \mathrm{C}$ and $4 \mathrm{ml}$ of boron tribromine $1 \mathrm{M}$ were added dropwise. The solution was mixed for $3 \mathrm{~h}$ and neutralised by adding a solution of sodium hydroxide $1 \mathrm{~N}$ and the extraction was made with ethyl acetate $(3 \mathrm{X} 30 \mathrm{ml})$. The organic fraction was collected, dried over magnesium sulfate and evaporated to give, without further purifications, $471 \mathrm{mg}(99 \%)$ of product 3 .

${ }^{1} \mathrm{H}$ NMR (DMSO-d6, 298K, 599.902 MHz): 3.07 (s, $\left.6 \mathrm{H},-\mathrm{N}-\left(\underline{\mathrm{C}}_{3}\right)_{2}\right) ; 6.86\left(\mathrm{~d},{ }^{3} \mathrm{~J}=9.0 \mathrm{~Hz}, 2 \mathrm{H}_{\mathrm{ar}}\right) ; 6.98\left(\mathrm{dd},{ }^{3} \mathrm{~J}=\right.$ $\left.8.7 \mathrm{~Hz},{ }^{4} \mathrm{~J}=2.4 \mathrm{~Hz}, 1 \mathrm{H}_{\mathrm{ar}}\right) ; 7.39\left(\mathrm{~d},{ }^{4} \mathrm{~J}=2.4 \mathrm{~Hz}, 1 \mathrm{H}_{\mathrm{ar}}\right) ; 7.78$ $\left(\mathrm{d},{ }^{3} \mathrm{~J}=8.7 \mathrm{~Hz}, 1 \mathrm{H}_{\mathrm{ar}}\right) ; 7.86\left(\mathrm{~d},{ }^{3} \mathrm{~J}=9.0 \mathrm{~Hz}, 2 \mathrm{H}_{\mathrm{ar}}\right), 9.71(1 \mathrm{H}$, $\mathrm{OH})$

2-(6-((2-(4-(dimethylamino)phenyl)benzo[d]thiazol-6yl)oxy)hexyl)isoindoline-1,3-dione: 4

To a solution of $\mathrm{N}-(6$-Bromohexyl)phthalimide $(860 \mathrm{mg}, 2.77 \mathrm{mmol})$ in $60 \mathrm{ml}$ of acetone were added $1 \mathrm{~g}$ of potassium carbonate and a solution of compound 3 $(450 \mathrm{mg}, 1,66 \mathrm{mmol})$ in $10 \mathrm{ml}$ of acetone. The mixture was refluxed 3 days. After cooling down to room temperature, the solid was filtered off and the solvent was evaporated. Crude product was dissolved in $5 \mathrm{ml}$ of dichloromethane and petroleum ether was added until precipitation. The white solid was isolated to give $715 \mathrm{mg}(86 \%)$ of compound 4 .

${ }^{1} \mathrm{H}$ NMR $\left(\mathrm{CDCl}_{3}, 298 \mathrm{~K}, 599.902 \mathrm{MHz}\right): 1.44(\mathrm{~m}$, $\left.2 \mathrm{H},-\mathrm{CH}_{2}-\mathrm{CH}_{2}-\mathrm{CH}_{2}-\right)$; 1.54 (m, $2 \mathrm{H},-\mathrm{CH}_{2}-\mathrm{CH}_{2}-\mathrm{CH}_{2}-$ ); $1.73\left(\mathrm{~m}, 2 \mathrm{H}, \quad-\mathrm{CH}_{2}-\mathrm{CH}_{2}-\mathrm{CH}_{2-}\right) ; 1.82(\mathrm{~m}, 2 \mathrm{H}$, $\left.-\mathrm{CH}_{2}-\mathrm{C}_{2}-\mathrm{CH}_{2}-\right) ; 3.05\left(\mathrm{~s}, 6 \mathrm{H},-\mathrm{N}-\left(\mathrm{CH}_{3}\right)_{2}\right) ; 3.71\left(\mathrm{t},{ }^{3} \mathrm{~J}=\right.$ $\left.7.2 \mathrm{~Hz}, 2 \mathrm{H},-\mathrm{CH}_{2}-\mathrm{CH}_{2}-\mathrm{NPht}\right) ; 4.00(\mathrm{t}, 3 \mathrm{~J}=6.4 \mathrm{~Hz}, 2 \mathrm{H}$, $\left.-\mathrm{C}_{2} \mathrm{O}-\right) ; 6.74\left(\mathrm{~d},{ }^{3} \mathrm{~J}=8.9 \mathrm{~Hz}, 2 \mathrm{H}_{\mathrm{ar}}\right) ; 7.03\left(\mathrm{dd},{ }^{3} \mathrm{~J}=8.9 \mathrm{~Hz}\right.$, $\left.{ }^{4}=2.4 \mathrm{~Hz}, 1 \mathrm{H}_{\mathrm{ar}}\right) ; 7.28\left(\mathrm{~d}, 4 \mathrm{~J}=2.4 \mathrm{~Hz}, 1 \mathrm{H}_{\mathrm{ar}}\right) ; 7.70(\mathrm{~m}$, $\left.2 \underline{\mathrm{H}}_{\mathrm{Pht}}\right) ; 7.85\left(\mathrm{~m}, 1 \mathrm{H}_{\mathrm{ar}}, 2 \mathrm{H}_{\mathrm{Pht}}\right) ; 7,90\left(\mathrm{~d}, 3 \mathrm{~J}=8.9 \mathrm{~Hz}, 2 \mathrm{H}_{\mathrm{ar}}\right)$.

${ }^{13} \mathrm{C} \mathrm{NMR}\left(\mathrm{CDCl}_{3}, 298 \mathrm{~K}, 150.86 \mathrm{MHz}\right): 25.7(1 \mathrm{C}$, $\left.-\mathrm{CH}_{2}-\mathrm{CH}_{2}-\mathrm{CH}_{2-}\right)$; $26.6\left(1 \mathrm{C},-\mathrm{CH}_{2}-\mathrm{CH}_{2}-\mathrm{CH}_{2-}\right)$; 28.5 (1C, $\left.-\mathrm{CH}_{2}-\mathrm{CH}_{2}-\mathrm{CH}_{2}-\right) ; 29.2$ (1C, $\left.-\mathrm{CH}_{2}-\mathrm{CH}_{2}-\mathrm{CH}_{2-}\right) ; 37.9$ (1C, $\left.-\mathrm{CH}_{2}-\mathrm{CH}_{2}-\mathrm{N}_{\mathrm{Pht}}\right) ; 40.1 \quad\left(2 \mathrm{C}, \quad-\mathrm{N}-\left(\mathrm{CH}_{3}\right)_{2}\right) ; 68.4$ (1C, $\left.-\mathrm{OCH}_{2}-\right) ; 105.1\left(1 \mathrm{C}_{\mathrm{ar}}\right) ; 111.7\left(2 \mathrm{C}_{\mathrm{ar}}\right) ; 115.3\left(1 \mathrm{C}_{\mathrm{ar}}\right) ; 121.6$ $\left(1 \mathrm{C}_{\mathrm{ar}}\right) ; 122.7\left(1 \mathrm{C}_{\mathrm{ar}}\right) ; 123.1\left(2 \mathrm{C}_{\mathrm{Pht}}\right) ; 128.5\left(2 \mathrm{C}_{\mathrm{ar}}\right) ; 132.1$

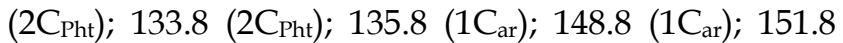
$\left(1 \mathrm{C}_{\mathrm{ar}}\right) ; 156.5\left(1 \mathrm{C}_{\mathrm{ar}}\right) ; 166.2\left(1 \mathrm{C}_{\mathrm{ar}}\right) ; 168.4$ (2C, COPht

HRMS (ESI): $m / z$ for $\mathrm{C}_{29} \mathrm{H}_{29} \mathrm{~N}_{3} \mathrm{O}_{3} \mathrm{~S}$, calculated 499.1930; found $500.2005[\mathrm{M}+\mathrm{H}]^{+}$
4-(6-((6-aminohexyl)oxy)benzo[d]thiazol-2-yl)-N,N-d imethylaniline: $\mathbf{5}$

Compound 4 (700mg, $1.40 \mathrm{mmol})$ was refluxed $2 \mathrm{~h}$ in $15 \mathrm{ml}$ of hydrazine hydrate. After cooling down, product was extracted with dichloromethane $(3 \mathrm{x}$ $30 \mathrm{ml}$ ) and the organic fraction was washed twice with $10 \mathrm{ml}$ of brine. The organic phase was dried over magnesium sulphate and evaporated to afford to $512 \mathrm{mg}(99 \%)$ of compound 5 as a yellow oil.

${ }^{1} \mathrm{H} \mathrm{NMR}\left(\mathrm{CDCl}_{3}, 298 \mathrm{~K}, 599.902 \mathrm{MHz}\right): 1.42(\mathrm{~m}$, $\left.4 \mathrm{H}, \mathrm{CH}_{2}-\mathrm{CH}_{2}-\mathrm{CH}_{2}\right) ; 1.48\left(\mathrm{~m}, 2 \mathrm{H},-\mathrm{CH}_{2}-\mathrm{C}_{2}-\mathrm{CH}_{2}\right) ; 1.83$ $\left(\mathrm{m}, 2 \mathrm{H},-\mathrm{CH}_{2}-\mathrm{CH}_{2}-\mathrm{CH}_{2}\right) ; 2.72\left(\mathrm{t},{ }^{3} \mathrm{~J}=6.4 \mathrm{~Hz}, 2 \mathrm{H}\right.$, $\left.-\mathrm{CH}_{2}-\mathrm{C}_{2}-\mathrm{NH}_{2}\right) ; 3.05\left(\mathrm{~s}, 6 \mathrm{H},-\mathrm{N}-\left(\mathrm{CH}_{3}\right)_{2}\right) ; 4.02\left(\mathrm{t}, 2 \mathrm{H},{ }^{3} \mathrm{~J}=\right.$ $\left.6.4 \mathrm{~Hz},-\underline{\mathrm{C}}_{2} \mathrm{O}-\right) ; 6.74\left(\mathrm{~d}, 3 \mathrm{~J}=8.9 \mathrm{~Hz}, 2 \mathrm{H}_{\mathrm{ar}}\right) ; 7.02(\mathrm{dd}, 3 \mathrm{~J}=$ $\left.8.9 \mathrm{~Hz},{ }^{4} \mathrm{~J}=2.4 \mathrm{~Hz}, 1 \mathrm{H}_{\mathrm{ar}}\right) ; 7.30\left(\mathrm{~d},{ }^{4} \mathrm{~J}=2.4 \mathrm{~Hz}, 1 \mathrm{H}_{\mathrm{ar}}\right) ; 7.84$ (d, $\left.1 \mathrm{H}, \mathrm{H}_{\mathrm{ar}}\right) ; 7,90\left(\mathrm{~d}, 3 \mathrm{~J}=8.9 \mathrm{~Hz}, 2 \mathrm{H}_{\mathrm{ar}}\right)$

${ }^{13} \mathrm{C}$ NMR $\left(\mathrm{CDCl}_{3}, 298 \mathrm{~K}, 150.860 \mathrm{MHz}\right): 26.0$ (1C, $-\mathrm{CH}_{2}-\mathrm{CH}_{2}-\mathrm{CH}_{2-}$ ); $26.7\left(1 \mathrm{C},-\mathrm{CH}_{2}-\mathrm{CH}_{2}-\mathrm{CH}_{2-}\right) ; 29.3(1 \mathrm{C}$, $\left.-\mathrm{CH}_{2}-\mathrm{CH}_{2}-\mathrm{CH}_{2}-\right) ; 33.8\left(1 \mathrm{C},-\mathrm{CH}_{2}-\mathrm{CH}_{2}-\mathrm{CH}_{2}\right) ; 40.2$ (2C,

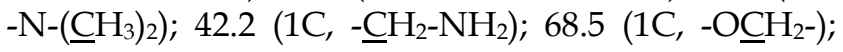
$105.1\left(1 \mathrm{C}_{\mathrm{ar}}\right) ; 111.7\left(2 \mathrm{C}_{\mathrm{ar}}\right) ; 115.4\left(1 \mathrm{C}_{\mathrm{ar}}\right) ; 121.7\left(1 \mathrm{C}_{\mathrm{ar}}\right) ; 122.7$ $\left(1 \mathrm{C}_{\mathrm{ar}}\right) ; 128.5\left(2 \mathrm{C}_{\mathrm{ar}}\right) ; 135.8\left(1 \mathrm{C}_{\mathrm{ar}}\right) ; 148.9\left(1 \mathrm{C}_{\mathrm{ar}}\right) ; 151.9$ $\left(1 \mathrm{C}_{\mathrm{ar}}\right) ; 156.6\left(1 \mathrm{C}_{\mathrm{ar}}\right) ; 166.4\left(1 \mathrm{C}_{\mathrm{ar}}\right)$

HRMS (ESI): $m / z$ for $\mathrm{C}_{21} \mathrm{H}_{27} \mathrm{~N}_{3} \mathrm{OS}$, calculated 369.1875; found $370.1946[\mathrm{M}+\mathrm{H}]^{+}$and 371.2032 $[\mathrm{M}+2 \mathrm{H}]^{2+}$

2-chloro-N-(6-((2-(4-(dimethylamino)phenyl)benzo[d ]thiazol-6-yl)oxy)hexyl)acetamide: 6

To a solution of compound 5 (500mg, $1.35 \mathrm{mmol}$ ) and triethylamine $(565 \mu \mathrm{l}, 4.06 \mathrm{mmol})$ in $15 \mathrm{ml}$ of dry THF at $0{ }^{\circ} \mathrm{C}$, was added dropwise a solution of chloroacetyl chloride $(650 \mu \mathrm{l}, 4.06 \mathrm{mmol})$ in $5 \mathrm{ml}$ of dry THF. The mixture was stirred $3 \mathrm{H}$ and $60 \mathrm{ml}$ of water was added. The solution was stored at $4^{\circ} \mathrm{C}$ overnight. Yellowish crystals were filtered off to give $499 \mathrm{mg}$ (83\%) of compound 6 .

${ }^{1} \mathrm{H}$ NMR $\left(\mathrm{CDCl}_{3}, 298 \mathrm{~K}, 599.902 \mathrm{MHz}\right): 1.42$ (m, $\left.4 \mathrm{H},-\mathrm{CH}_{2}-\mathrm{CH}_{2}-\mathrm{CH}_{2}-\right) ; 1.48$ (m, $2 \mathrm{H},-\mathrm{CH}_{2}-\mathrm{CH}_{2}-\mathrm{CH}_{2}-$ ); $1.83\left(\mathrm{~m}, 2 \mathrm{H},-\mathrm{CH}_{2}-\mathrm{C}_{2}-\mathrm{CH}_{2-}\right) ; 3.05\left(\mathrm{~s}, 6 \mathrm{H},-\mathrm{N}-\left(\mathrm{CH}_{3}\right)_{2}\right)$; 3.35 (dt, $\left.{ }^{3} \mathrm{~J}=6.1 \mathrm{~Hz},{ }^{3} \mathrm{~J}=7.2 \mathrm{~Hz}, 2 \mathrm{H},-\mathrm{CH}_{2}-\mathrm{CH}_{2}-\mathrm{NHCO}-\right)$; $4.02\left(\mathrm{t}, 3 \mathrm{~J}=6.4 \mathrm{~Hz}, 2 \mathrm{H},-\mathrm{CH}_{2} \mathrm{O}-\right) ; 4.05\left(\mathrm{~s}, 2 \mathrm{H},-\mathrm{CH}_{2}-\mathrm{Cl}\right)$; 6.59 (bs, $1 \mathrm{H},-\mathrm{NHCO}) ; 6.74\left(\mathrm{~d}, 3 \mathrm{~J}=8.9 \mathrm{~Hz}, 2 \mathrm{H}_{\mathrm{ar}}\right) ; 7.02$ $\left(\mathrm{dd},{ }^{3} \mathrm{~J}=8.9 \mathrm{~Hz}, \overline{4}=2.4 \mathrm{~Hz}, 1 \mathrm{H}_{\mathrm{ar}}\right) ; 7.30\left(\mathrm{~d},{ }^{4} \mathrm{~J}=2.4 \mathrm{~Hz}\right.$, $\left.1 \mathrm{H}_{\mathrm{ar}}\right) ; 7.86\left(\mathrm{~d}, 1 \mathrm{H}, \mathrm{H}_{\mathrm{ar}}\right) ; 7,90\left(\mathrm{~d},{ }^{3} \mathrm{~J}=8.9 \mathrm{~Hz}, 2 \mathrm{H}_{\mathrm{ar}}\right)$

${ }^{13} \mathrm{C} \mathrm{NMR}\left(\mathrm{CDCl}_{3}, 298 \mathrm{~K}, 150.860 \mathrm{MHz}\right): 25.8$ (1C, $-\mathrm{CH}_{2}-\mathrm{CH}_{2}-\mathrm{CH}_{2-}$ ); 26.6 (1C, $\left.-\mathrm{CH}_{2}-\mathrm{CH}_{2}-\mathrm{CH}_{2}-\right) ; 29.2$ (1C, $\left.-\mathrm{CH}_{2}-\mathrm{CH}_{2}-\mathrm{CH}_{2}-\right) ; 29.3\left(1 \mathrm{C},-\mathrm{CH}_{2}-\mathrm{CH}_{2}-\mathrm{CH}_{2-}\right) ; 39.8$ (1C, $\left.-\mathrm{CH}_{2}-\mathrm{NH}_{2}\right) ; 40.2\left(2 \mathrm{C},-\mathrm{N}-\left(\mathrm{CH}_{3}\right)_{2}\right) ; 42.7$ (1C, $\left.-\underline{\mathrm{CH}} 2-\mathrm{Cl}\right)$; $68.4\left(1 \mathrm{C},-\mathrm{OCH}_{2-}\right) ; 105.1\left(1 \mathrm{C}_{\mathrm{ar}}\right) ; 111.8\left(2 \mathrm{C}_{\mathrm{ar}}\right) ; 115.4$ $\left(1 \mathrm{C}_{\mathrm{ar}}\right) ; 122.6\left(1 \mathrm{C}_{\mathrm{ar}}\right) ; 125.5\left(1 \mathrm{C}_{\mathrm{ar}}\right) ; 128.6\left(2 \mathrm{C}_{\mathrm{ar}}\right) ; 135.8$

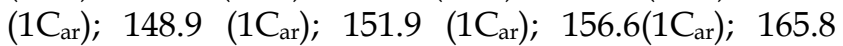
(1CO); $166.4\left(1 \mathrm{C}_{\mathrm{ar}}\right)$

HRMS (ESI): $m / z$ for $\mathrm{C}_{23} \mathrm{H}_{28} \mathrm{ClN}_{3} \mathrm{O}_{2} \mathrm{~S}$, calculated 445.1591; found $446.1663[\mathrm{M}+\mathrm{H}]^{+}$ 
2,2',2"-(10-(2-((6-((2-(4-(dimethylamino))phenyl)benzo [d] thiazol-6-yl)oxy)hexyl)amino)-2-oxoethyl)-1,4,7,10 -tetraazacyclododecane-1,4,7-triyl)triacetic acid: 7

To a solution of DO3A-tBu $(300 \mathrm{mg}, 0.58 \mathrm{mmol})$ and potassium carbonate $(226 \mathrm{mg}, 2 \mathrm{mmol})$ in $20 \mathrm{~mL}$ of dry acetonitrile was added a solution of $6(310 \mathrm{mg}$, $0.7 \mathrm{mmol}$ ) in $15 \mathrm{~mL}$ of dry acetonitrile. The reaction mixture was stirred for $16 \mathrm{~h}$ at $90^{\circ} \mathrm{C}$. After cooling, the solid was filtered off and the solvent was evaporated. The crude product was purified by flash chromatography (eluent: ethyl acetate/methanol 95/5) and $407 \mathrm{mg}(76 \%)$ of product 7 were isolated as a yellow oil.

${ }^{1} \mathrm{H}$ NMR $\left(\mathrm{CDCl}_{3}, 298 \mathrm{~K}, 599.902 \mathrm{MHz}\right): 1.40(\mathrm{~m}$, $\left.2 \mathrm{H},-\mathrm{CH}_{2}-\mathrm{CH}_{2}-\mathrm{CH}_{2}-\right) ; 1.44$ (s, $\left.18 \mathrm{H},-\mathrm{C}\left(\mathrm{CH}_{3}\right)_{3}\right) ; 1.45$ (s, 9H, - $\left.\mathrm{C}\left(\mathrm{CH}_{3}\right)_{3}\right) ; 1.48\left(\mathrm{~m}, 2 \mathrm{H},-\mathrm{CH}_{2}-\mathrm{C}_{2}-\mathrm{CH}_{2}-\right) ; 1.61$ (m, $\left.2 \mathrm{H},-\mathrm{CH}_{2}-\mathrm{CH}_{2}-\mathrm{CH}_{2}-\right) ; 1.81$ (m, $2 \mathrm{H},-\mathrm{CH}_{2}-\mathrm{CH}_{2}-\mathrm{CH}_{2}-$ ); 2.25 (bs, $8 \mathrm{H}, \quad-\mathrm{NCH}_{2}-\mathrm{CH}_{2} \mathrm{~N}$ ); 2.55 (bs, $4 \mathrm{H}$, $\left.-\mathrm{NCH}_{2}-\underline{\mathrm{C}}_{2} \mathrm{~N}-\right) ; \quad 2.85$ (bs, $6 \mathrm{H}, \quad-\mathrm{NCH}_{2}-\mathrm{C}_{2} \mathrm{~N}-$, $\left.-\mathrm{N}-\underline{\mathrm{C}}_{2}-\mathrm{CONH}-\right) ; 3.05$ (s, $\left.6 \mathrm{H},-\mathrm{N}-\left(\underline{\mathrm{CH}}_{3}\right)_{2}\right) ; 3.22$ (dt, ${ }^{3} \mathrm{~J}=$ $\left.6.1 \mathrm{~Hz},{ }^{3} \mathrm{~J}=5.9 \mathrm{~Hz}, 2 \mathrm{H},-\mathrm{CH}_{2}-\mathrm{NHCO}\right) ; 3.39$ (bs, $6 \mathrm{H}$, $\left.-\mathrm{N}-\underline{\mathrm{H}}_{2}-\mathrm{COOtBu}\right) ; 3.99\left(\mathrm{t},{ }^{3} \mathrm{~J}=6.4 \mathrm{~Hz}, 2 \mathrm{H},-\mathrm{C}_{2} \mathrm{O}-\right) ; 6.74$ $\left(\mathrm{d},{ }^{3} \mathrm{~J}=8.9 \mathrm{~Hz}, 2 \mathrm{H}_{\mathrm{ar}}\right) ; 7.0\left(\mathrm{dd},{ }^{3} \mathrm{~J}=8.9 \mathrm{~Hz},{ }^{4}=2.4 \mathrm{~Hz}, 1 \mathrm{H}_{\mathrm{ar}}\right)$; $7.31\left(\mathrm{~d},{ }^{4}=2.4 \mathrm{~Hz}, 1 \mathrm{H}_{\mathrm{ar}}\right) ; 7.62(\mathrm{t}, 1 \mathrm{H}, \mathrm{N} \underline{\mathrm{HCO}}) ; 7.84(\mathrm{~d}$, $\left.{ }^{3} \mathrm{~J}=8.9 \mathrm{~Hz}, \mathrm{H}_{\mathrm{ar}}\right) ; 7,90\left(\mathrm{~d}, 2 \mathrm{H}_{\mathrm{ar}}\right)$

${ }^{13} \mathrm{C}$ NMR $\left(\mathrm{CDCl}_{3}, 298 \mathrm{~K}, 150.860 \mathrm{MHz}\right): 25.4$ (1C, $\left.-\mathrm{CH}_{2}-\mathrm{CH}_{2}-\mathrm{CH}_{2-}\right) ; 26.4\left(1 \mathrm{C},-\mathrm{CH}_{2}-\mathrm{CH}_{2}-\mathrm{CH}_{2}-\right) ; 27.5$ (3C, $\left.-\mathrm{C}\left(\mathrm{CH}_{3}\right)_{3}\right) ; \quad 27.6 \quad\left(6 \mathrm{C}, \quad-\mathrm{C}\left(\underline{\mathrm{CH}}_{3}\right)_{3}\right) \quad ; 28.8 \quad$ (1C, $\left.-\mathrm{CH}_{2}-\mathrm{CH}_{2}-\mathrm{CH}_{2}-\right) ; 29.1$ (1C, $\left.-\mathrm{CH}_{2}-\mathrm{CH}_{2}-\mathrm{CH}_{2}-\right)$; 38.7 (1C, $\left.-\mathrm{CH}_{2}-\mathrm{NHCO}-\right) ; \quad 39.9 \quad\left(2 \mathrm{C}, \quad-\mathrm{N}-\left(\mathrm{CH}_{3}\right)_{2}\right) ; \quad 48.1 \quad(4 \mathrm{C}$, $\left.-\mathrm{NCH}_{2}-\mathrm{CH}_{2} \mathrm{~N}-\right)$; 52.0 (4C, $\left.-\mathrm{NCH}_{2}-\mathrm{CH}_{2} \mathrm{~N}-\right)$; 55.1 (2C, $\left.-\mathrm{N}-\mathrm{CH}_{2}-\mathrm{COOtBu}\right) ; 55.3$ (1C, $\left.-\mathrm{N}-\mathrm{CH}_{2}-\mathrm{COOtBu}\right) ; 56.0$ $\left(1 \mathrm{C},-\mathrm{N}-\mathrm{CH}_{2}-\mathrm{CONH}-\right) ; 68.2\left(1 \mathrm{C},-\mathrm{OCH}_{2-}\right) ; 81.2$ (2C, $\left.-\underline{\mathrm{C}}\left(\mathrm{CH}_{3}\right)_{3}\right) ; 81.3\left(1 \mathrm{C},-\underline{\mathrm{C}}\left(\mathrm{CH}_{3}\right)_{3}\right) ; 104.7 \quad\left(1 \mathrm{C}_{\mathrm{ar}}\right) ; 111.3$ $\left(2 \mathrm{C}_{\mathrm{ar}}\right) ; 115.1\left(1 \mathrm{C}_{\mathrm{ar}}\right) ; 120.9\left(1 \mathrm{C}_{\mathrm{ar}}\right) ; 122.1\left(1 \mathrm{C}_{\mathrm{ar}}\right) ; 128.1$ $\left(2 \mathrm{C}_{\mathrm{ar}}\right) ; 135.3$ (1 $\left.1 \mathrm{C}_{\mathrm{ar}}\right) ; 148.3\left(1 \mathrm{C}_{\mathrm{ar}}\right) ; 151.5\left(1 \mathrm{C}_{\mathrm{ar}}\right) ; 156.3$ $\left(1 \mathrm{C}_{\mathrm{ar}}\right) ; 165.9\left(1 \mathrm{C}_{\mathrm{ar}}\right) ; 171.0$ (1C, - $\left.\mathrm{CONH}-\right) ; 171.8$ (2C, -COOtBu); 172.1 (1C, -COOtBu)

HRMS (ESI): $m / z$ for $\mathrm{C}_{49} \mathrm{H}_{77} \mathrm{~N}_{7} \mathrm{O}_{8} \mathrm{~S}$ calculated 923.5554; found $924.5622[\mathrm{M}+\mathrm{H}]^{+}$

\section{tri-tert-butyl}

2,2',2"--(10-(2-((6-((2-(4-(dimethylamino)phenyl)benzo [d] thiazol-6-yl)oxy)hexyl)amino)-2-oxoethyl)-1,4,7,10 -tetraazacyclododecane-1,4,7-triyl)triacetate: $\mathbf{L}_{\mathbf{3}}$

To a solution of $7(350 \mathrm{mg}, 0.38 \mathrm{mmol})$ in $10 \mathrm{ml}$ of dichloromethane was added $10 \mathrm{ml}$ of trifluoroacetic acid. The solution was stirred $3 \mathrm{~h}$ at room temperature and the solvents were evaporated. The crude product was purified by flash chromatography on RPC18 silica (eluent: $\left.\mathrm{H}_{2} \mathrm{O} / \mathrm{Methanol}\right) .207 \mathrm{mg}$ (82\%) of ligand $\mathbf{L}_{3}$ were isolated as a yellow powder.
${ }^{1} \mathrm{H} \mathrm{NMR}\left(\mathrm{CDCl}_{3}, 298 \mathrm{~K}, 599.902 \mathrm{MHz}\right): 1.03$ (bs, $4 \mathrm{H},-\mathrm{CH}_{2}-\mathrm{CH}_{2}-\mathrm{CH}_{2}-$ ); 1.28 (bs, $4 \mathrm{H},-\mathrm{CH}_{2}-\mathrm{CH}_{2}-\mathrm{CH}_{2}-$ ); 2.28 (bs, $6 \mathrm{H}, \mathrm{NCH}_{2}-\mathrm{C}_{2} \mathrm{~N}, \mathrm{CH}_{2}-\mathrm{NHCO}$ ); 3.10-3.26 (bs, $\left.20 \mathrm{H}, \mathrm{NCH}_{2}-\mathrm{CH}_{2} \mathrm{~N}, \mathrm{CH}_{2}-\mathrm{NHCO}, \mathrm{N}-\left(\mathrm{CH}_{3}\right)_{2}\right) ; 3.57$ (bs, $\left.4 \mathrm{H}, \mathrm{N}-\underline{\mathrm{C}}_{2}-\mathrm{COOH}\right) ; 3.74$ (bs, $4 \mathrm{H}, \mathrm{N}-\mathrm{CH}_{2}-\mathrm{COOH}$, $\mathrm{C}_{2} \mathrm{O}$ ); 5.66 (bs, $2 \mathrm{H}_{\mathrm{ar}}$ ); 6.06 (bs, $\left.1 \mathrm{H}_{\mathrm{ar}}\right) ; 6.51$ (bs, $1 \mathrm{H}_{\mathrm{ar}}$ ); 6.95 (bs, $\left.1 \mathrm{H}, \mathrm{H}_{\mathrm{ar}}\right) ; 7.33$ (d, 1H, $\left.\mathrm{H}_{\mathrm{ar}}\right)$

HRMS (ESI): $m / z$ for $\mathrm{C}_{37} \mathrm{H}_{53} \mathrm{~N}_{7} \mathrm{O}_{8} \mathrm{~S}$ calculated 755.3676; found $757.3824[\mathrm{M}+2 \mathrm{H}]^{2+}$ and 758.3910 $[\mathrm{M}+3 \mathrm{H}]^{3+}$

General procedure for the preparation of gadolinium (III) complexes:

$\operatorname{Gd}\left(L_{x}\right)(x=2,3)$ complexes were prepared by mixing aqueous solutions of $\mathrm{GdCl}_{3}$ and the ligand $\mathrm{Lx}$ in equimolar quantities and adjusting the $\mathrm{pH}$ to 5.5 with aqueous $\mathrm{NaOH}(0.1 \mathrm{mM})$. The solutions were allowed to react for $2 \mathrm{~h}$ at room temperature while the $\mathrm{pH}$ was continuously adjusted. The absence of free metal ion was checked in each sample using the xylenol orange test.

\section{Determination of Octanol-Water Partition Coefficient (log $\mathrm{P}_{\text {oct/water }}$ )}

The partition coefficient of $\mathrm{Gd}\left(\mathrm{L}_{3}\right)$ was determined, following the method previously used, as the ratio of the concentration of the compound in octanol and concentration of the compound in the aqueous phase [11, 12].

Partition coefficient $(\mathrm{P})=\frac{[\text { solute }] \text { octanol phase }}{[\text { solute }] \text { aqueous phase }}$

The logarithm of the partition coefficient is referred to as the $\log \mathrm{P}$ value. The "shake flask" method was used for the determination of $\log \mathrm{P}$. Water saturated with octanol and octanol saturated with water were used in the experiments. The benzothiazol ring absorbs strongly at approximately $330 \mathrm{~nm}$; therefore, the partition was quantified using UV spectrophotometry with a PerkinElmer Lambda $19 \mathrm{UV}$-vis spectrophotometer. For each phase, the maximum wavelength was verified. A 1:1 volume ratio was used for the partitioning of the solution with $\mathrm{Gd}\left(\mathrm{L}_{3}\right)$. In a 2-mL Eppendorf tube, $0.5 \mathrm{~mL}$ of a $100 \mu \mathrm{M}$ solution of $\mathrm{Gd}\left(\mathrm{L}_{3}\right)$ was added to $0.5 \mathrm{~mL}$ of the saturated phase of 1-octanol. Each sample was centrifuged for $30 \mathrm{~min}$. $\mathrm{Gd}\left(\mathrm{L}_{3}\right)$ concentrations were determined in each phase using standard curves.

\section{Synthesis of functionalised MWNTs (f-MWNTs)}

The synthesis of $f$-MWNTs was performed in three sequential steps as described in Scheme 2 and previously reported [29]. 


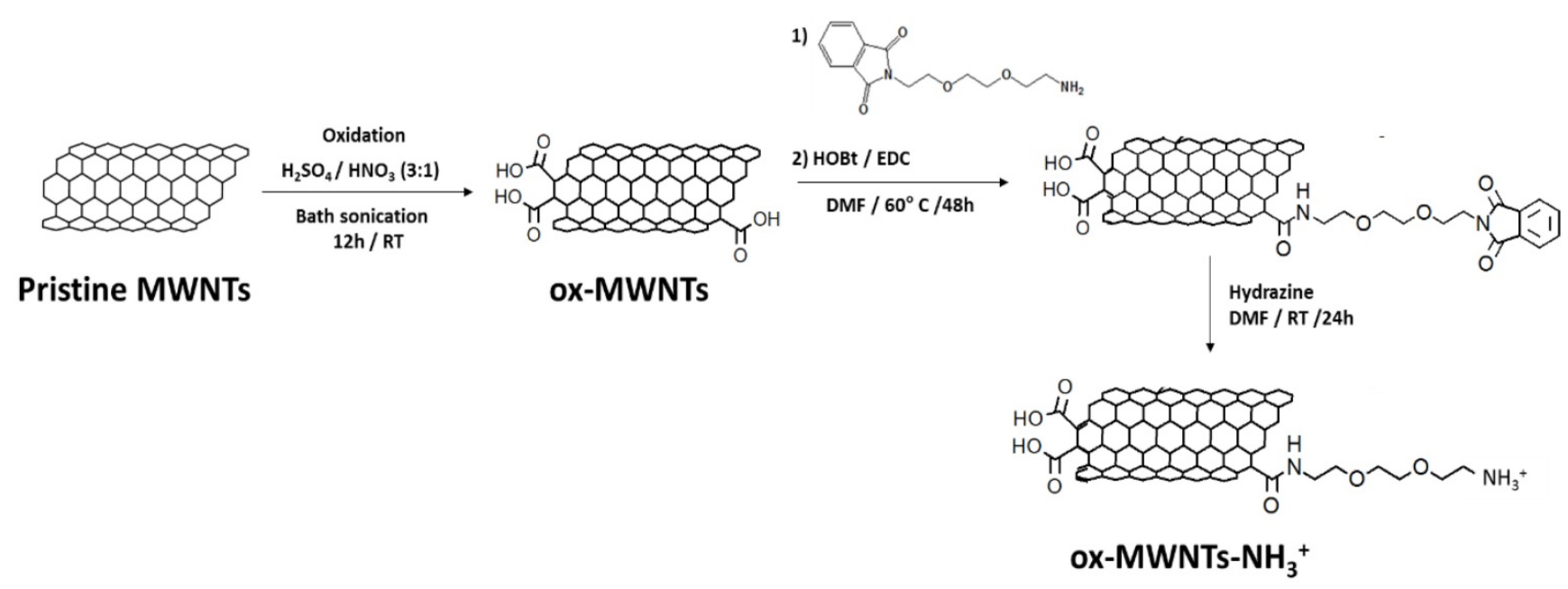

Scheme 2. Synthesis of functionalised MWNTs (f-MWNTs). Pristine MWNTs were incubated under strong acidic conditions to produce oxidised MWNTs (ox-MWNTs). The carboxylic acid moieties of ox-MWNTs were reacted with a phthalimide-protected amine-terminated spacer via amide coupling reaction, in the presence of $\mathrm{N}$-hydroxybenzotriazole (HOBt) and 1-ethyl-3-(3-dimethylaminopropyl)carbodiimide hydrochloride (EDC) (1:2:2:2 molar ratio). Cleavage of the protection group was performed under strong alkaline conditions using hydrazine, yielding carboxylate and amine-functionalised $\mathrm{MWNTs}\left(\mathrm{ox}-\mathrm{MWNTs}-\mathrm{NH}_{3}{ }^{+}\right.$). $\mathrm{RT}$ : room temperature; $\mathrm{DMF}$ : dimethylformamide.

(i) Oxidation: pristine MWNTs (100 mg) were suspended in $25 \mathrm{~mL} \mathrm{HNO}_{3}: \mathrm{H}_{2} \mathrm{SO}_{4}$ (1:3), which was bath sonicated for $12 \mathrm{~h}$ (water was regularly changed to prevent overheating). Subsequently, the mixture was added to $500 \mathrm{~mL}$ of distilled water $\left(\mathrm{dH}_{2} \mathrm{O}\right)$ and vacuum filtered through a $0.2 \mu \mathrm{m}$ hydrophilic membrane. The black solid (oxidised MWNTs, ox-MWNTs) was collected from the filter and purified

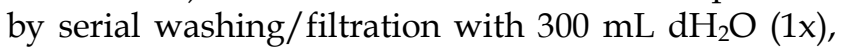
$300 \mathrm{~mL} 5 \% \mathrm{NaOH}(1 \mathrm{x})$ and $200 \mathrm{~mL}$ methanol (1x).

(ii) Amidation: ox-MWNTs ( $34 \mathrm{mg}, 0.076$ mmol) were suspended in $40 \mathrm{~mL}$ dimethylformamide (DMF) under bath sonication for $10 \mathrm{~min}$ and subsequently mixed with 1-ethyl-3-(3-dimethylaminopropyl)carbodiimide hydrochloride (EDC. $\mathrm{HCl}$ ) ( $29.1 \mathrm{mg}, 0.152 \mathrm{mmol}), \mathrm{N}$ - hydroxybenzotriazole (HoBt) ( $20.5 \mathrm{mg}, 0.152 \mathrm{mmol})$ and phthalimideprotected amine-terminated spacer $(\sim 42.3 \mathrm{mg}, 0.152$ mmol; synthesis described in Supplementary Material). The reaction was carried out under stirring at $60^{\circ} \mathrm{C}$ for $24 \mathrm{~h}$, after which the ox-MWNTs were recovered by vacuum filtration through a $0.2 \mu \mathrm{m}$ hydrophobic membrane. The collected black solid (amidated ox-MWNTs) was further purified by serial washing/filtration with $100 \mathrm{~mL} \mathrm{DMF} \mathrm{(1x)} \mathrm{and} 100 \mathrm{~mL}$ methanol.

(iii) Deprotection: amidated ox-MWNTs (32 mg) were suspended in $20 \mathrm{~mL}$ DMF under bath sonication for $10 \mathrm{~min}, 6 \mathrm{~mL}$ hydrazine monohydrate were then added to the reaction mixture and the suspension was continuously stirred for $24 \mathrm{~h}$ at room temperature (RT). The deprotected ox-MWNTs (ox-MWNTs- $\mathrm{NH}_{3}{ }^{+}$) were recovered by vacuum filtration through a $0.2 \mu \mathrm{m}$ hydrophobic filter and further purified via serial washing/filtration with $100 \mathrm{~mL} \mathrm{DMF} \mathrm{(1x)} \mathrm{and} 100 \mathrm{~mL}$ methanol (final yield $\sim 30 \mathrm{mg}$ ).

\section{Kaiser test}

Ninhydrin assay reagents (phenol/ethanol 42.55 $\mathrm{M}, \mathrm{KCN} /$ pyridine $0.02 \mathrm{M}$ and ninhydrin/ethanol 0.28 M) were prepared in the fume hood. Five hundred microliters of each reagent were added to $1 \mathrm{mg}$ of ox-MWNTs or ox-MWNTs- $\mathrm{NH}_{3}{ }^{+}$, followed by bath sonication for $1 \mathrm{~min}$ and incubation at $100^{\circ} \mathrm{C}$ for 7 min. Subsequently, $4.5 \mathrm{~mL}$ of ethanol:water (60:40) were added to the suspension, which was further centrifuged for $10 \mathrm{~min}$ at 1811 x g $(2000 \mathrm{rpm}$; Eppendorf 5810R, Fisher Scientific UK). The UV-vis absorbance of the supernatant was measured at 575 $\mathrm{nm}$ against a standard curve of 2,2'-(Ethylenedioxy)bis(ethylamine) (Fig. S1) in a Lambda 35 spectrophotometer (Perkin Elmer, USA).

\section{Thermogravimetric (TGA) analysis}

Samples of pristine MWNTs, ox-MWNTs and ox-MWNTs- $\mathrm{NH}_{3}{ }^{+}(\sim 1 \mathrm{mg})$ were loaded in platinum pans and the analysis was carried out on a TGA Q500 (TA instruments, USA). Reaction was performed under constant nitrogen gas flow $(90 \mathrm{~mL} / \mathrm{min})$ and consisted of temperature increase (from RT) and stabilisation at $100^{\circ} \mathrm{C}$ for $20 \mathrm{~min}$, followed by a controlled temperature increase $\left(10^{\circ} \mathrm{C} / \mathrm{min}\right)$ up to $1000{ }^{\circ} \mathrm{C}$. Data analysis was performed using the Advantage software (TA instruments, USA).

\section{Conjugation of $L_{2}$ and $L_{3}$ or $G d\left(L_{2}\right)$ and $G d\left(L_{3}\right)$ to $f$-MWNTs}

$\mathrm{Gd}\left(\mathrm{L}_{2}\right)$ and $\mathrm{Gd}\left(\mathrm{L}_{3}\right)$ were conjugated to oxMWNTs or ox-MWNTs- $\mathrm{NH}_{3}{ }^{+}$at a molar ratio of 1:10 (complex:f-MWNTs), as shown in Scheme 3. Since it is 
difficult to calculate the number of benzene rings per $f$-MWNT, as well as the number of $f$-MWNTs in each sample, a ratio of 1 molecule of $\mathrm{Gd}\left(\mathrm{L}_{2 / 3}\right)$ to 10 benzene units was adopted. ox-MWNTs or ox-MWNTs- $\mathrm{NH}_{3}{ }^{+}$ were dispersed in $4 \mathrm{~mL} \mathrm{dH}_{2} \mathrm{O}$ under bath sonication for $5 \mathrm{~min}$ and the ligands were added separately to each dispersion, which was briefly sonicated. The different dispersions (ox-MWNTs $+\mathrm{Gd}\left(\mathrm{L}_{2}\right)$, oxMWNTs $+\mathrm{Gd}\left(\mathrm{L}_{3}\right)$, ox-MWNTs- $\mathrm{NH}_{3}{ }^{+}+\mathrm{Gd}\left(\mathrm{L}_{2}\right)$ and ox-MWNTs- $\mathrm{NH}_{3}{ }^{+}+\mathrm{Gd}\left(\mathrm{L}_{3}\right)$ were continuously stirred (300 rpm) for $48 \mathrm{~h}$ at RT. For recovery of the ligand:f-MWNT conjugates, the dispersions were vacuum filtered through $0.2 \mu \mathrm{m}$ pore hydrophilic membranes, the black solid pellets (conjugates) were collected and purified via serial washing/filtration

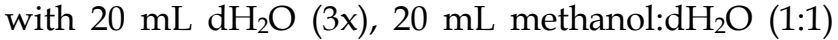
(2x) and $20 \mathrm{~mL}$ methanol (2x) (Scheme 3). Samples of the filtrate (supernatant containing unbound ligand) and washing fractions were collected for quantification via inductively coupled plasma mass spectrometry (ICP-MS) and fluorimetry. Samples of conjugates $\left(\mathrm{Gd}\left(\mathrm{L}_{2}\right)\right.$ :ox-MWNTs, $\mathrm{Gd}\left(\mathrm{L}_{3}\right)$ :ox-MWNTs, $\mathrm{Gd}\left(\mathrm{L}_{2}\right)$ :ox-MWNTs- $\mathrm{NH}_{3}{ }^{+}$and $\mathrm{Gd}\left(\mathrm{L}_{3}\right)$ :ox-MWNTs$\mathrm{NH}_{3}{ }^{+}$) were collected for quantification of bound ligand via ICP-MS. The same protocol was followed for conjugation of $\mathrm{Gd}^{3+}$-free $\mathrm{L}_{2 / 3}$ to ox-MWNTs or ox-MWNTs- $\mathrm{NH}_{3}{ }^{+}$.

\section{Quantification of ligand loading by ICP-MS}

ICP-MS quantification of $\mathrm{Gd}^{3+}$ conjugated to $f$-MWNTs was performed as described previously for $\mathrm{Fe}^{3+}$ conjugated to CNTs [30]. Suitable dilutions of $\mathrm{Gd}^{3+}$ standards (Ricca Chemical, TX, USA) were prepared in $10 \%$ nitric acid to obtain a $\mathrm{Gd}^{3+}$ standard curve in the range of $10^{-3}-10^{3}$ parts per million (ppm) $\left(1 \mathrm{ppm} \sim 10^{3} \mu \mathrm{g} / \mathrm{L} \sim 6.36 \mu \mathrm{mol} / \mathrm{L} ; \mathrm{MW}=157.25 \mathrm{~g} / \mathrm{mol}\right)$. To remove any traces of metal, $15 \mathrm{~mL}$ non-sterile tubes were pre-treated with $10 \mathrm{~mL} \mathrm{HCl}(0.1 \mathrm{M})$ at $50^{\circ} \mathrm{C}$ for $30 \mathrm{~min}$ and dried before usage. Samples of conjugates $\left(\mathrm{Gd}\left(\mathrm{L}_{2}\right)\right.$ :ox-MWNTs, $\mathrm{Gd}\left(\mathrm{L}_{3}\right)$ :ox-MWNTs, $\mathrm{Gd}\left(\mathrm{L}_{2}\right)$ :ox-MWNTs- $\mathrm{NH}_{3}{ }^{+}, \mathrm{Gd}\left(\mathrm{L}_{3}\right)$ :ox-MWNTs- $\left.\mathrm{NH}_{3}{ }^{+}\right)$, filtrate and washes were digested by incubation with $2 \mathrm{~mL} \mathrm{HNO}_{3}(67 \%)$ for $24 \mathrm{~h}$ at $80^{\circ} \mathrm{C}$. The resulting solutions were diluted with $\mathrm{dH}_{2} \mathrm{O}$ to reach a concentration within the calibration range (average final volume of $10 \mathrm{~mL}$ ) and subsequently centrifuged at $4000 \mathrm{rpm}$ for $30 \mathrm{~min}$ (Eppendorf 5810R, Fisher Scientific UK) to ensure the removal of $f$-MWNTs from the solution. The $\mathrm{Gd}^{3+}$ content in the samples was measured against a standard curve of $\mathrm{Gd}^{3+}$ (Fig. S2) using the NexION 350D ICP mass spectrometer (Perkin Elmer, USA) with Cetac ASX 520 autosampler and Syngistix software. Sample flow was kept at 0.2 $\mathrm{mL} / \mathrm{min}$, argon flow (main, aux, nebuliser) at 18, 1.2 and $1.0 \mathrm{~L} / \mathrm{min}$, and RF coil power was $1600 \mathrm{~W}$. An average of 5 different replicates was performed per sample measurement (with 50 sweeps/replicate).

\section{Quantification of complex loading by fluorimetry}

The excitation and emission

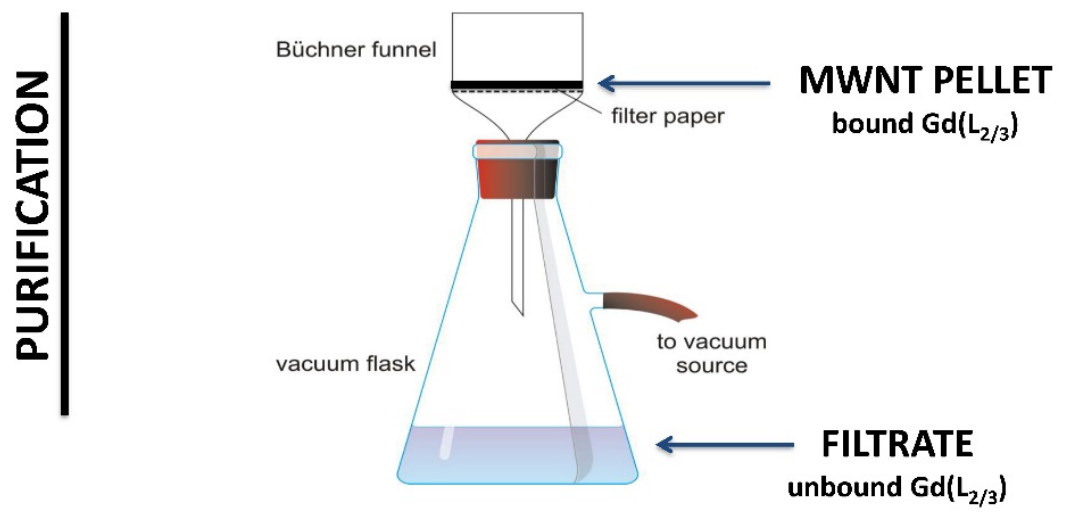

Scheme 3. Conjugation of $\mathbf{G d}\left(\mathrm{L}_{2}\right)$ or $\mathbf{G d}\left(\mathrm{L}_{3}\right)$ to $f-M W N T s$. $G d\left(L_{2}\right)$ or $G d\left(L_{3}\right)$ were conjugated to ox-MWNTs or ox-MWNTs- $\mathrm{NH}_{3}{ }^{+}$by incubation under stirring for $48 \mathrm{~h}$ at $\mathrm{RT}$. To remove the unbound complex, the conjugates $\left(\mathrm{Gd}\left(\mathrm{L}_{2}\right)\right.$ :ox-MWNTs, $\mathrm{Gd}\left(\mathrm{L}_{3}\right)$ :ox-MWNTs, $\mathrm{Gd}\left(\mathrm{L}_{2}\right)$ : ox-MWNTs- $\mathrm{NH}_{3}{ }^{+}$and $\mathrm{Gd}\left(\mathrm{L}_{3}\right)$ :ox-MWNTs- $\mathrm{NH}_{3}{ }^{+}$) were vacuum filtered through a hydrophilic membrane. The pellet recovered on the filter contains the bound complex, whereas the supernatant (filtrate) contains unbound complex. 


\section{Radiolabelling of $L_{2 / 3}$ and $L_{2 / 3}: f-M W N T s$ conjugates with 111 In}

Radiolabelling $\mathrm{L}_{2}$ with ${ }^{111} \mathrm{In}$ has been reported previously [11]. In this work, radiolabelling was performed on $\mathrm{L}_{2} / 3$ :ox-MWNTs and $\mathrm{L}_{2 / 3}$ :ox-MWNTs$\mathrm{NH}_{3}{ }^{+}$conjugates with the labelling approach modified accordingly. Dispersions of $f$-MWNTs $(1 \mathrm{mg} / \mathrm{ml}$, in $\mathrm{H}_{2} \mathrm{O}$ ) were mixed with ${ }^{111} \mathrm{InCl}_{3}$ buffered in ammonium acetate ( $\mathrm{pH}$ 5.5). Solutions were incubated for $30 \mathrm{~min}$ at room temperature and were vortexed every $5 \mathrm{~min}$ for thorough mixing. Solutions of $\mathrm{L}_{2 / 3}(1 \mathrm{mg} / \mathrm{ml}$ in $\mathrm{H}_{2} \mathrm{O}$ ) were also subjected to the same labelling procedures. The labelling efficiency was assessed by iTLC (mobile phase, 3.5\% $\mathrm{NH}_{4}{ }^{+}$: methanol (1:1), $\mathrm{pH}$ 11). The auto-radioactivity of each TLC strip was developed and counted quantitatively using a Cyclone phosphor detector (Packard Biosciences). EDTA solution $(0.1 \mathrm{M}, 1 / 20, \mathrm{v} / \mathrm{v})$ was then added to the $f$-MWNTs mixture to chelate any excess unreacted ${ }^{111} \mathrm{InCl}_{3}$. Labelled ${ }^{111} \mathrm{In}\left(\mathrm{L}_{2 / 3}\right): f-\mathrm{MWNTs}$ dispersions were pelleted by centrifugation at $13,000 \mathrm{rpm}$ for 30 min while unreacted ${ }^{111} \mathrm{In}$ remained in the supernatant. The pelleted ${ }^{111} \operatorname{In}\left(\mathrm{L}_{2 / 3}\right): f$-MWNTs were resuspended in 1X PBS at $1 \mathrm{mg} / \mathrm{ml}$ for injection. iTLC (mobile phase: $0.1 \mathrm{M}$ ammonium acetate buffer containing $50 \mathrm{mM}$ EDTA) was carried out after addition of EDTA and after centrifugation. For labelled ${ }^{111} \operatorname{In}\left(\mathrm{L}_{2} / 3\right)$, solutions were buffered with $10 \mathrm{X}$ PBS to become isotonic for injection without the addition of EDTA.

The stability of radiolabelling was examined by incubating ${ }^{111} \operatorname{In}\left(\mathrm{L}_{2 / 3}\right)$ :f-MWNTs dispersions and ${ }^{111} \operatorname{In}\left(\mathrm{L}_{2 / 3}\right)$ solutions with an equal volume of PBS or FBS at $37^{\circ} \mathrm{C}$ for $24 \mathrm{~h}$. The solutions were subjected to iTLC analyses as described above.

Different amounts of ${ }^{111} \mathrm{InCl}_{3}$ were used for radiolabelling for different studies according to the labelling efficiency and radioactivity required. The radioactivity in each injection dose was $\sim 10 \mathrm{MBq}$ and $\sim 1 \mathrm{MBq}$ for SPECT/CT imaging and $\gamma$-scintigraphy studies respectively.

\section{Animals}

In vivo experiments were conducted under the authority of project and personal licences granted by the UK Home Office and the UKCCCR Guidelines (1998). Female C57BL/6 mice aged 6-8 weeks were purchased from Charles River (UK) for all the experiments. Details about animal husbandry and welfare are provided in Supplementary Material.

\section{SPECT/CT}

The biodistribution of intravenously (i.v.)-injected ${ }^{111}$ In-labelled $\mathrm{L}_{2 / 3}, \mathrm{~L}_{2 / 3}$ :ox-MWNTs, and $\mathrm{L}_{2 / 3}$ :ox-MWNTs- $\mathrm{NH}_{3}{ }^{+}$was firstly examined by $3 \mathrm{D}$ whole body SPECT/CT imaging. Mice were injected via tail vein with $100 \mu \mathrm{g}$ of labelled ${ }^{111} \operatorname{In}\left(\mathrm{L}_{2 / 3}\right): f-$ MWNTs $\left(1 \mathrm{mg} / \mathrm{ml}\right.$ in PBS) or $\operatorname{In}\left(\mathrm{L}_{2 / 3}\right)$ alone $(100 \mu \mathrm{g})$ under isoflurane anaesthesia. SPECT/CT scans were carried out on the same animal at multiple time points: immediately after injection, at $4 \mathrm{~h}$ and $24 \mathrm{~h}$. Mice were placed in the prone position and SPECT scans were acquired over 24 projections $(60 \mathrm{~s}$ per projection), using a 4-head scanner with $1.4 \mathrm{~mm}$ pinhole collimators, for a total acquisition time of 30-40 min (Nano-SPECT/CT, USA) [27]. CT scans (45 kVP X-ray) were performed after each SPECT. All images were reconstructed by MEDISO software (Medical Imaging Systems), and SPECT and CT images were merged using the VivoQuant ${ }^{\mathrm{TM}}$ software (inviCRO, USA).

\section{Y-scintigraphy}

Quantitative organ uptake of i.v. injected ${ }^{111}$ In-labelled $\mathrm{L}_{2 / 3}$ and $\mathrm{L}_{2 / 3}$ :ox-MWNTs- $\mathrm{NH}_{3}{ }^{+}$was assessed by $\gamma$-scintigraphy. Mice were injected via a tail vein with ${ }^{111} \mathrm{In}\left(\mathrm{L}_{2 / 3}\right)$ : ox-MWNTs- $\mathrm{NH}_{3}{ }^{+}(50 \mu \mathrm{g}$ per mouse) or ${ }^{111} \operatorname{In}\left(\mathrm{L}_{2 / 3}\right) \quad(50 \mu \mathrm{g}$ per mouse $)$ under isoflurane anaesthesia. At 2, 5, 10 and $30 \mathrm{~min}$ after injection, blood samples were collected from the lateral tail vein and the mice were perfused with $50 \mathrm{~mL}$ of heparinised saline solution $(50 \mathrm{U} / \mathrm{mL})$ through the left ventricle of the heart to wash out the ${ }^{111}$ In-labelled compounds remaining in circulation or loosely attached to tissues. Major organs (including brain) were excised, weighed and the radioactivity was measured by gamma counting (LKB Wallac 1282 Compugamma, PerkinElmer). Results (mean \pm SD, $\mathrm{n}=3$ ) are expressed as $\%$ of injected dose per gram of organ (\% ID/g of organ), unless otherwise stated.

\section{Capillary depletion}

Brain tissues were subjected to capillary depletion, i.e. separation of brain parenchyma from blood vessels (capillaries), as described previously [31]. Briefly, each brain was homogenised in a glass homogeniser containing $1 \mathrm{~mL}$ of ice-cold depletion buffer (10 mM HEPES in HBSS, pH 7.4) via 15 stokes of the pestle, followed by addition of $1.6 \mathrm{~mL}$ of depletion buffer containing $26 \%$ dextran $(148 \mathrm{kDa})$ and repeated pestle homogenisation (3 strokes). The homogenates were centrifuged at $3220 \times g$ (Eppendorf 5810R, Fisher Scientific UK) for $15 \mathrm{~min}$ to separate parenchyma (supernatant) and capillaries (pellet), and the radioactivity was measured using gamma counting (LKB Wallac 1282 Compugamma, PerkinElmer). Results (mean $\pm \mathrm{SD}, \mathrm{n}=3$ ) are expressed as $\%$ of injected dose per brain fraction (\% ID/brain fraction) followed by the analysis of brain parenchyma to blood ratio. 


\section{Statistical analysis}

Data are presented as mean \pm standard deviation (mean $\pm \mathrm{SD}$ ) of at least two different experiments, unless otherwise stated. Statistical analysis was performed on GraphPad Prism (GraphPad Software, CA, USA) using one-way ANOVA with Tukey's multi-comparison test, unless otherwise stated.

\section{Results and discussion}

\section{Synthesis and characterisation of $\mathbf{G d}\left(L_{2}\right)$, Gd $\left(L_{3}\right)$ and $f-M W N T s$}

The synthesis of the ligand $\mathrm{L}_{2}$ was previously reported and the synthetic pathway of $\mathrm{L}_{3}$ is outlined in Scheme 1. 4-(6-methoxybenzo[d]thiazol-2-yl)aniline 1 was prepared according to the procedures described in the literature [12]. Then, in a reductive amination reaction, the $\mathrm{N}$-dimethylated derivative $\mathbf{2}$ was obtained in very high yield, and the ether function was quantitatively cleaved with boron tribromide. The linker was then introduced by nucleophilic substitution between product 3 and $\mathrm{N}$-(6-Bromohexyl)phthalimide and the removal of the phtalimide protecting group was performed with hydrazine hydrate, giving the corresponding amine 5, which was acylated with chloroacetyl chloride to afford the amide derivative 6 . Protected compound 7 was obtained by $\mathrm{N}$-alkylation of tri-tert-butyl 2,2',2"-(1,4,7,10-tetraazacyclododecane-1,4,7-triyl)triac etate (DO3A-tBu) with 6 under classical conditions in presence of a base, in acetonitrile. The acid-sensitive tert-butyl protecting groups were then removed with trifluoroacetic acid in dichloromethane to give the final ligand $\mathrm{L}_{3}$. The gadolinium complexes $\mathrm{Gd}\left(\mathrm{L}_{2}\right)$ and $\mathrm{Gd}\left(\mathrm{L}_{3}\right)$ were formed by adding the gadolinium salt at a controlled $\mathrm{pH}$ of 5,5 .

Since the conjugation (via adsorption) of ligands on MWNTs is dependent on the hydrophobicity of the probes, an increase in the $\log \mathrm{P}$ values of the ligands could be beneficial. The ligand structures diverge on the spacer used for conjugation of the $\mathrm{PiB}$ derivative to Do3A, with amide or ether linkages being used in $\mathrm{L}_{2}$ and $\mathrm{L}_{3}$, respectively. The lipophilicity of $\mathrm{L}_{3} / \mathrm{Gd}\left(\mathrm{L}_{3}\right)$ was also modulated by introducing two methyl groups on the amine function. Consequentially, the $\log P$ value of $G d\left(L_{3}\right)$ shows a gain in lipophilicity $(\log \mathrm{P}=0.63)$ compared to $\mathrm{Gd}\left(\mathrm{L}_{2}\right)(\log \mathrm{P}=0.03)$.

Due to high hydrophobicity, pristine MWNTs are not easily dispersed in water. Moreover, the reduced diameter $(\sim 9.5 \mathrm{~nm})$ of the MWNTs used in this study makes them prone to aggregation in aqueous solution [32]. For this reason, pristine MWNTs were initially oxidised by incubation (under sonication) with a mixture of sulphuric and nitric acid, to promote chemical exfoliation of the nanotube surface, addition of carboxylic $(\mathrm{COOH})$ groups and, consequently, increasing water dispersibility and decreasing possible cell toxicity (Scheme 2). Functionalisation via oxidation has also been shown to enhance renal clearance and decrease reticuloendothelial system accumulation [33]. The presence of carboxylate groups on the side-wall defects and tips of MWNTs also allows for introduction of additional functional groups [34]. Indeed, oxidised MWNTs (ox-MWNTs) were further functionalised via amidation reaction between $\mathrm{COOH}$ groups and a phthalimide-protected amine-terminated spacer (Scheme 2). Deprotection of the spacer was achieved by alkaline treatment, yielding ox-MWNTs with positively charged primary amine groups (ox-MWNTs- $\mathrm{NH}_{3}{ }^{+}$). The introduction of functional groups to the surface of pristine MWNTs was confirmed by TGA and Kaiser test. TGA allows accurate determination of MWNT functionalisation by assessing sample weight loss upon exposure to gradually increasing temperature (under inert atmosphere). The weight loss is directly related to the introduction of functional groups onto the side-walls of $f$-MWNTs. As shown in Fig. 2A, pristine MWNTs exhibit high thermal stability (i.e. residual weight loss) up to $700{ }^{\circ} \mathrm{C}$, after which the benzene backbone starts to decompose. In comparison, substantial weight loss was detected for ox-MWNTs at $600{ }^{\circ} \mathrm{C}$ $(\sim 13.5 \%)$, indicating the thermal degradation of carboxylic groups. Additional weight loss was detected for the amidated ox-MWNTs at $600{ }^{\circ} \mathrm{C}$ $(\sim 9.2 \%$, total mass loss $=22.7 \%)$, which confirms the degradation of amine groups on the surface of ox-MWNTs- $\mathrm{NH}_{3}{ }^{+}$.

Surface functionalisation with amine groups was further confirmed using Kaiser test, a semiquantitative colorimetric test based on the reaction of the ninhydrin reagent with free primary amine groups [35]. Fig. 2B shows a representative assay image, with the development of pink colour (i.e. presence of amine groups) for ox-MWNTs- $\mathrm{NH}_{3}{ }^{+}$, while no colour development is seen for ox-MWNTs (do not contain primary amine groups). An average of $203 \mu \mathrm{mol}$ of amine groups per gram of ox-MWNTs- $\mathrm{NH}_{3}{ }^{+}$was obtained using the Kaiser test, a value considerably smaller than that determined by TGA $\left(687 \mu \mathrm{mol} \mathrm{NH} \mathrm{N}_{2} / \mathrm{g}\right.$ of ox-MWNTs- $\mathrm{NH}_{3}{ }^{+}$) (Table 1). This difference is most probably caused by residual aggregation of ox-MWNTs- $\mathrm{NH}_{3}{ }^{+}$, which limits the number of amine groups available to react with the ninhydrin reagent $[25,35]$. The amine content of ox-MWNTs- $\mathrm{NH}_{3}{ }^{+}$used this study is nevertheless similar to that reported in previous studies from our group, with values ranging from 100 to $530 \mu \mathrm{mol}$ of amine groups per gram of MWNTs generated by amidation reaction $[25,26,29,34]$. 
A

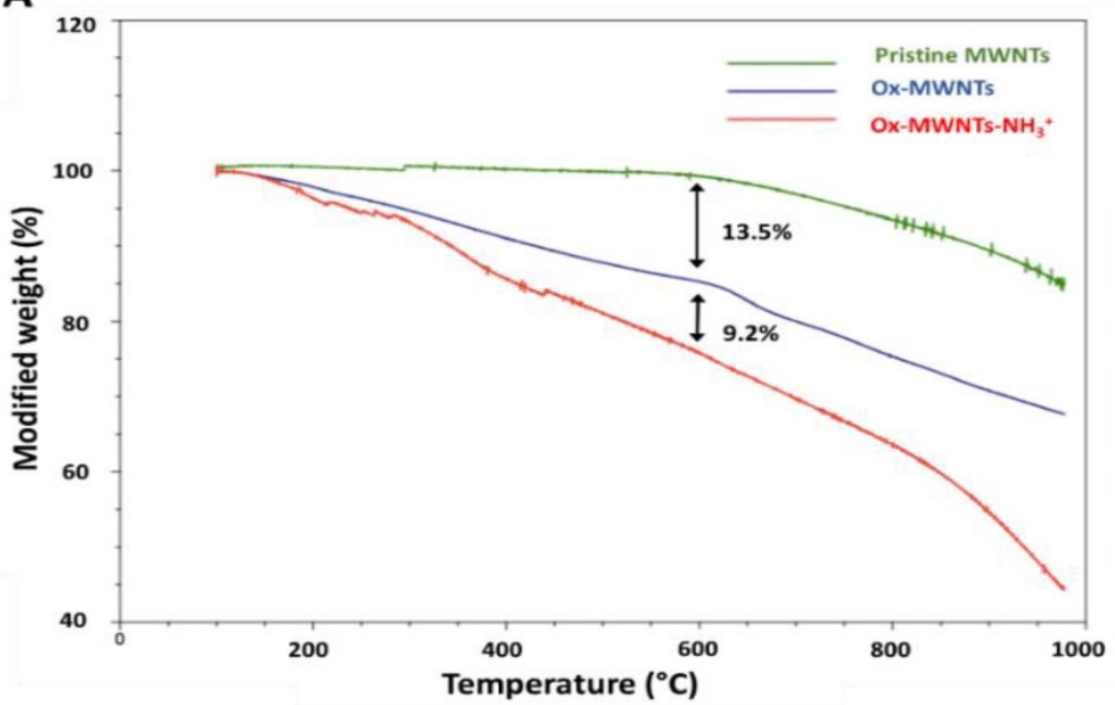

B

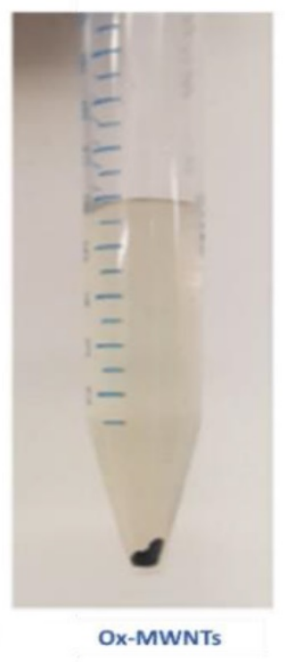

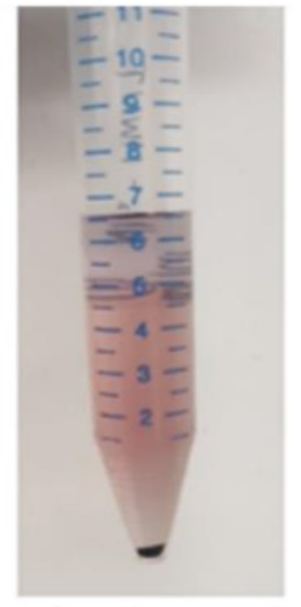

OX-MWNTs- $\mathrm{NH}_{3}{ }^{*}$

Figure 2. Characterisation of $f$-MWNT functionalization using TGA and Kaiser test. (A) Thermal decomposition of pristine, oxidised (ox-MWNTs) or oxidised and aminated carbon nanotubes (ox-MWNTs- $\mathrm{NH}_{3}{ }^{+}$) under increasing temperature. Functional groups present on $\mathrm{f}-\mathrm{MWNTs}$, such as $\mathrm{COOH}$ and $\mathrm{NH}_{3}{ }^{+}$, are degraded at temperatures below $600^{\circ} \mathrm{C}$ (which is reflected by the increasing weight loss), whereas no significant degradation (i.e. residual weight loss) is seen with pristine MWNTs. (B) Representative image of the colorimetric detection of free primary amine groups on the surface of MWNTs (via Kaiser test). No color development is seen with ox-MWNTs ( 1 $\mathrm{mg}$ ) (left), whereas development of pink coloration is seen with ox-MWNTs- $\mathrm{NH}_{3}{ }^{+}(1 \mathrm{mg})$ (right).

Table 1. Quantitative characterisation of MWNT functionalisation by TGA and Kaiser test.

\begin{tabular}{|l|l|l|l|}
\hline \multicolumn{1}{|c|}{$f$-MWNTs } & \multicolumn{2}{c|}{$\begin{array}{c}\boldsymbol{\mu} \text { mol of functional group per gram of } \\
\text { MWNTs }\end{array}$} & \\
\hline & TGA (a) & Kaiser test (b) & \\
\hline ox-MWNTs & $2446 \pm 770$ & - & $\mathrm{COOH}$ \\
\hline ox-MWNT- $-\mathrm{NH}_{3}{ }^{+}$ & $682 \pm 10$ & $203 \pm 21$ & $\mathrm{NH}_{2}$ \\
\hline
\end{tabular}

(a) Measured using TGA

(b) Measured by Kaiser test.

Taking into consideration the extent of MWNT oxidation determined by TGA $(2446 \pm 770 \mu \mathrm{mol}$ $\mathrm{COOH} / \mathrm{g}$ of ox-MWNTs), the data indicates that $\sim 1 / 3$ of the carboxylate groups were functionalised with the amine-terminated linker. The size of the $f$-MWNTs has been studied previously, with the mean diameter of ox-MWNTs measured between 6 and $12 \mathrm{~nm}$ and the mean length between 370 and $570 \mathrm{~nm}$, by transmission electron microscopy and subsequent image analysis with Image J [26, 33]. The amidation reaction and conjugation of ligands are not expected to affect nanotube length, due to absence of oxisiding acid in this step. Similar to what has been observed in our previous studies [25, 26, 33, 34], good water dispersibility was obtained for both ox-MWNTs and ox-MWNTs- $\mathrm{NH}_{3}{ }^{+}$(data not shown).

\section{Conjugation of $\mathbf{G d}\left(\mathrm{L}_{2}\right)$ or $\mathbf{G d}\left(\mathrm{L}_{3}\right)$ to $f-M W N T s$}

Since $\mathrm{Gd}\left(\mathrm{L}_{2}\right) / \mathrm{Gd}\left(\mathrm{L}_{3}\right)$ contain aromatic rings in their structure, the conjugation to ox-MWNTs or ox-MWNTs- $\mathrm{NH}_{3}{ }^{+}$- by simple mixing under stirring relied on hydrophobic interactions between the ligands and MWNTs. Conjugation was assessed by two complementary techniques, ICP-MS and fluorimetry, upon separation of MWNT-bound and unbound ligand fractions by vacuum filtration (Scheme 3). ICP-MS was used to quantify $\mathrm{Gd}^{3+}$ in MWNT-bound and unbound fractions, providing an indirect measurement of $\mathrm{Gd}\left(\mathrm{L}_{2 / 3}\right)$ conjugated to the MWNTs. Taking advantage of the intrinsic fluorescence of $\mathrm{L}_{2 / 3}$, fluorimetry was used to quantify the ligands in the unbound fraction, while quantification of the MWNT-bound fraction by this technique is hampered by the fluorescence-quenching properties of the MWNTs.

Table 2. Quantification of ligand loading onto f-MWNTS by ICP-MS and fluorimetry.

\begin{tabular}{|c|c|c|c|c|}
\hline \multirow[t]{3}{*}{$f$-MWNTs } & \multicolumn{4}{|c|}{ Hmol of ligand per gram of $f$-MWNTs (a) } \\
\hline & $\mathrm{Gd}\left(\mathrm{L}_{2}\right)$ & & $\mathrm{Gd}\left(\mathrm{L}_{3}\right)$ & \\
\hline & $\underline{\text { ICP-MS }}$ & $\underline{\text { Fluorimetry (c) }}$ & ICP-MS (b) & Fluorimetry \\
\hline ox-MWNTs & $389 \pm 438$ & $542 \pm 42$ & $222 \pm 70$ & $203 \pm 2$ \\
\hline ox-MWNT-NH ${ }_{3}^{+}$ & $60 \pm 14$ & $577 \pm 8$ & $105 \pm 33$ & $51 \pm 29$ \\
\hline
\end{tabular}

As shown in Table 2, higher levels of $\mathrm{Gd}\left(\mathrm{L}_{2}\right)$ and $\mathrm{Gd}\left(\mathrm{L}_{3}\right)$ were found conjugated to ox-MWNTs by ICP-MS (389 \pm 438 and $222 \pm 70 \mu \mathrm{mol}$ of complex/g of $f$-MWNTs, respectively) compared to ox-MWNT$\mathrm{NH}_{3}{ }^{+}(60 \pm 14$ and $105 \pm 33 \mu \mathrm{mol}$ of complex/g of $f$-MWNTs). Similarly, significantly higher levels of $\mathrm{Gd}\left(\mathrm{L}_{2 / 3}\right)$ were found conjugated to ox-MWNTs when 
loading was measured by fluorimetry $(p=0.0071$, two-way ANOVA). The favourable ligand loading onto ox-MWNTs is probably related to the steric hindrance generated by the amine-terminated spacer, which partly blocks the interaction between aromatic rings of ligands and $f$-MWNTs. A trend towards more efficient conjugation of $\mathrm{Gd}\left(\mathrm{L}_{2}\right)$ was also detected by both ICP-MS and fluorimetry (389 \pm 438 and $542 \pm 42$ $\mu$ mol of ligand/g of $f$-MWNTs, respectively), when compared to $\mathrm{Gd}\left(\mathrm{L}_{3}\right)(222 \pm 70$ and $203 \pm 2 \mu \mathrm{mol}$ of ligand/g of $f$-MWNTs) ( $\mathrm{p}=0.54$ for ICP-MS, $\mathrm{p}=0.0069$ for fluorimetry; two-way ANOVA). This observation could possibly be justified by the difference in hydrophobicity of $\mathrm{Gd}\left(\mathrm{L}_{2}\right)$ and $\mathrm{Gd}\left(\mathrm{L}_{3}\right)(\log \mathrm{P}=0.03$ and 0.63 , respectively).

\section{Radiolabelling of $L_{2 / 3}$ and $L_{2 / 3}: f-M W N T s$ conjugates with 111 In}

Since the PiB-DO3A derivatives have high affinity for both gadolinium(III) and indium(III), ( $\left.\mathrm{L}_{2 / 3}\right)$ :f-MWNTs conjugates prepared without $\mathrm{Gd}^{3+}$ were radiolabelled with ${ }^{111} \mathrm{In}^{3+}$, aiming at assessing the in vivo biodistribution and brain uptake of the constructs by SPECT/CT imaging and $\gamma$-scintigraphy with high sensitivity. Although indirect tracking of the $f$-CNT has been carried out in this study, it is worth reporting that label-free detection of $f$-CNTs in vivo has been previously reported by our group. Taking advantage of the optical properties of CNTs, we used Raman and multiphoton luminescence to confirm the direct presence of systemically-administered f-MWNTs in mouse brain [27]. Furthermore, the presence of CNTs was confirmed by TEM in both whole brain and capillary fractions after intravenous injection in mice [27]. The results matched the indirect detection carried out by radiolabelling. We therefore adapted radiolabelling method to confirm the conjugation and track the organ biodistribution of $\mathrm{L}_{2}$ and $\mathrm{L}_{3}$ ligands.

The labelling efficiency was determined by iTLC analyses. Mobile phase consisting of $3.5 \%$ $\mathrm{NH}_{4}{ }^{+}$:methanol (1:1) was used to test labelling efficiency of $\mathrm{L}_{2 / 3}$. As shown in Fig. 3A, labelled conjugates $\left({ }^{111} \operatorname{In}\left(\mathrm{L}_{2 / 3}\right)\right)$ were detected at the solvent front (labelling efficiency $>60 \%$ ). To test the labelling efficiency of ( $\left.\mathrm{L}_{2 / 3}\right)$ :f-MWNTs conjugates, a mobile buffer containing 50mM EDTA in $0.1 \mathrm{M}$ acetate buffer was used, with an average labelling efficiency $>85 \%$ (spots at application point) being determined (Fig. 3B). Removal of unconjugated ${ }^{111} \mathrm{In}$ (in the form of [111In]EDTA) or [ $\left.{ }^{111} \mathrm{In}\right] \mathrm{L}_{2} / 3$ ) from the final sample was achieved by centrifugation.

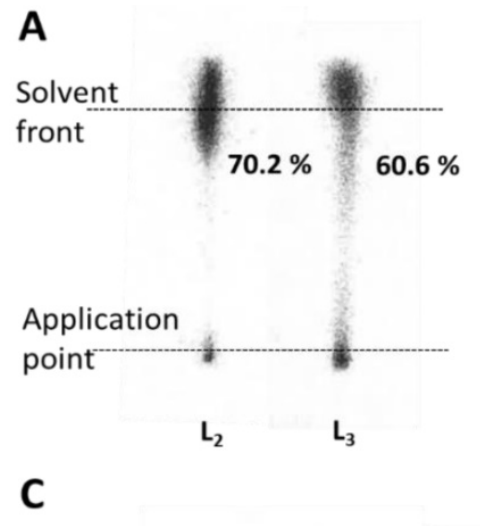

B

Solvent front

\section{front}

Solvent front

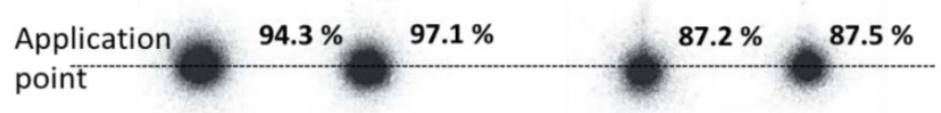

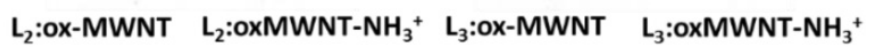

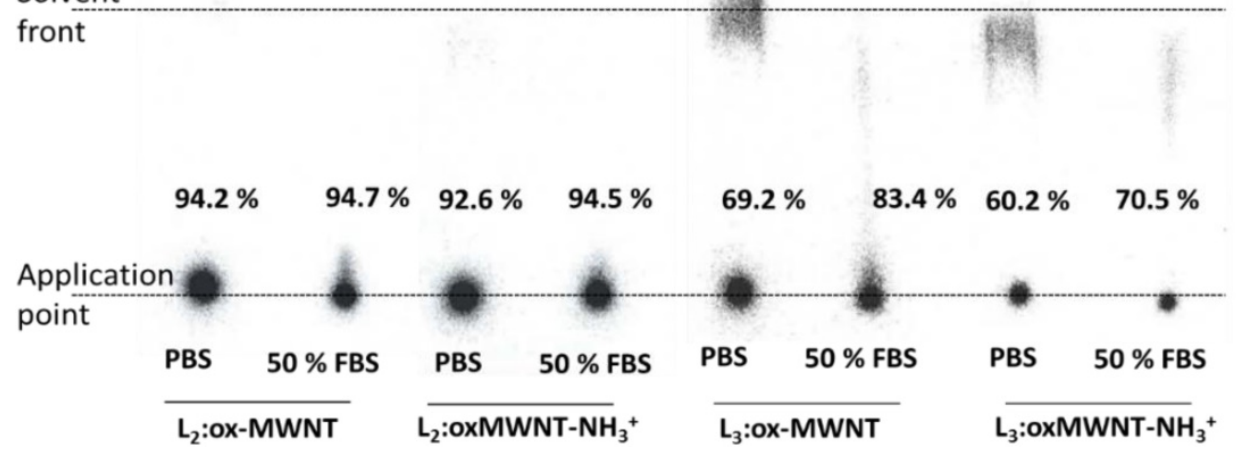

Figure 3. Labelling efficiency and stability studies of $111 \mathrm{ln}$-labelled $L_{2 / 3}$ and their $f$-MWNTs conjugates. Radiolabelling of $(A) L_{2 / 3}(B) L_{2 / 3}: 0 x-M W N T s$ and $\mathrm{L}_{2 / 3}$ :ox-MWNTs- $\mathrm{NH}_{3}{ }^{+}$with ${ }^{\prime \prime}$ 'In ${ }^{3+}$ was determined by iTLC analyses using $3.5 \% \mathrm{NH}_{4}{ }^{+}$: methanol $(1: 1$, $\mathrm{pH} 11)$ (for $\left.\mathrm{L}_{2 / 3}\right)$ and $0.1 \mathrm{M}$ ammonium acetate buffer containing 50 mM EDTA ( $\mathrm{pH} 5.5)$ (for the conjugates) as the mobile phase. Dispersions of $111 \mathrm{ln}\left(\mathrm{L}_{2 / 3}\right): f-M W N T s$ were treated with $0.1 \mathrm{M}$ EDTA $(1 / 20 \mathrm{v} / \mathrm{v}) \mathrm{prior}$ TLC run to chelate unreacted $111 \mathrm{ln}$. (C) After centrifugation and re-dispersion in PBS, dispersions were incubated with or without FBS $(1: 1, v / v)$ at $37^{\circ} \mathrm{C}$ for $24 \mathrm{~h}$. The labelling stability was examined by iTLC (mobile phase: $0.1 \mathrm{M}$ ammonium acetate buffer containing $50 \mathrm{mM}$ EDTA). 


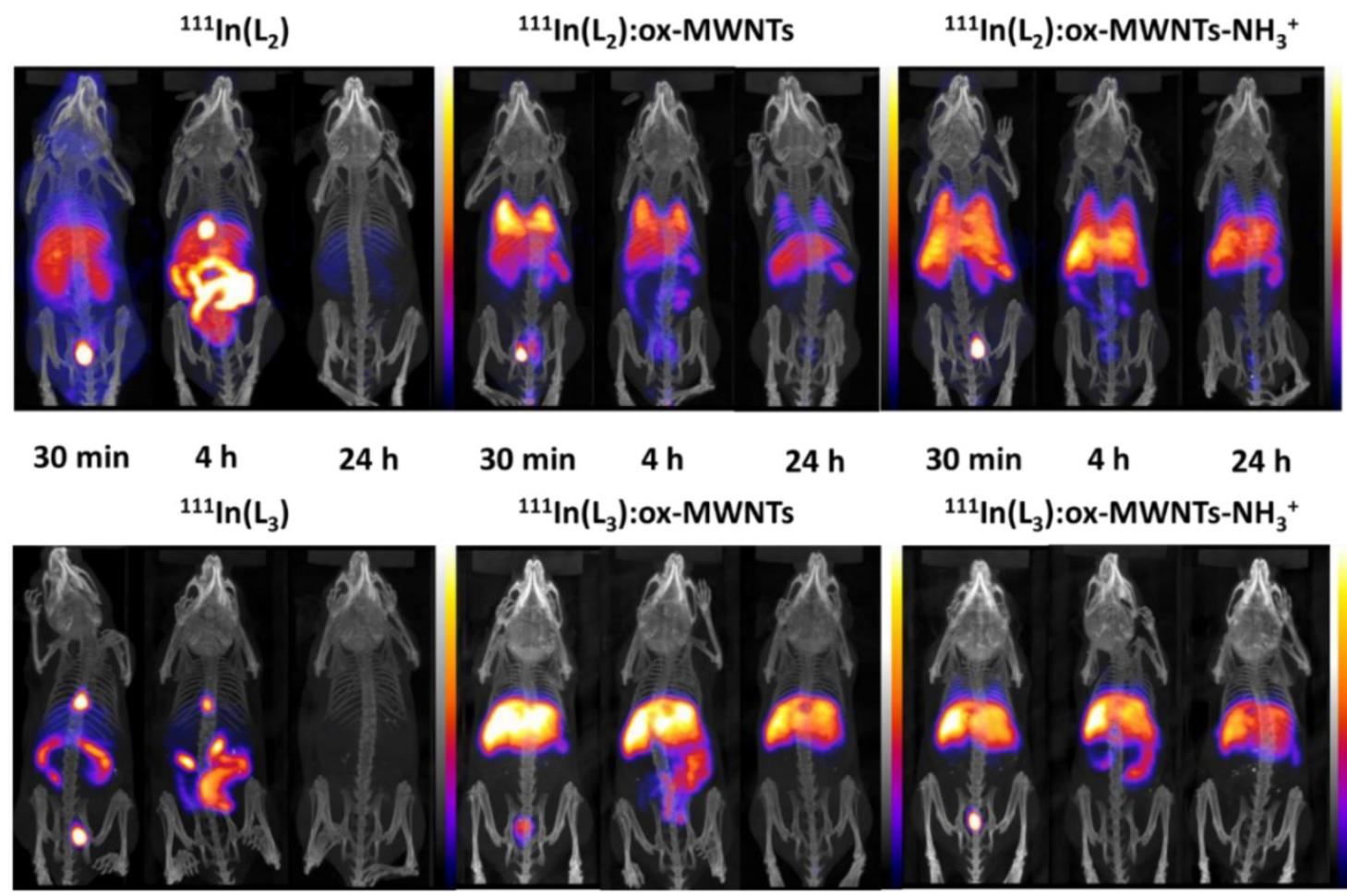

Figure 4. Whole body SPECT/CT imaging of 111 In-labelled $\mathbf{L}_{2 / 3}$ and $\mathbf{L}_{2 / 3}: f-M W N T s$ conjugates following i.v. injection. $C 57 B L / 6$ mice were injected via tail vein with $\sim 10 \mathrm{MBq}$ of non-conjugated complexes $111 \mathrm{ln}\left(\mathrm{L}_{2 / 3}\right)(100 \mu \mathrm{g})$ and their $f-M W N T s$ conjugates $11 / \mathrm{ln}\left(\mathrm{L}_{2 / 3}\right): \mathrm{ox}-\mathrm{MWNTs}$ and $111 \mathrm{ln}\left(\mathrm{L}_{2 / 3}\right): \mathrm{ox}-\mathrm{MWNTs}-\mathrm{NH} 3^{+}(200 \mu \mathrm{g})$. SPECT/CT imaging was carried out immediately after injection and at 4 and $24 \mathrm{~h}$ post injection.

The labelling stability was assessed upon incubation in PBS or $50 \%$ FBS at $37^{\circ} \mathrm{C}$ for $24 \mathrm{~h}$. The iTLC results revealed that greater radiochemical stability was obtained for ${ }^{111} \operatorname{In}\left(\mathrm{L}_{2}\right)$ :f-MWNTs than ${ }^{111} \operatorname{In}\left(\mathrm{L}_{3}\right): f-M W N T s$ conjugate. The presence of serum had no influence on the stability (Fig. 3C).

\section{Whole body SPECT/CT imaging of 111 In-labelled conjugates following i.v. injection}

Whole body SPECT/CT imaging of ${ }^{111}$ In-labelled free ligands $\left(\mathrm{L}_{2 / 3}\right)$ and $\left(\mathrm{L}_{2 / 3}\right)$ :f-MWNTs conjugates was performed to monitor the spatial distribution of the compounds upon i.v. administration in healthy mice. As shown in Fig. 4, marked differences in biodistribution were observed between ${ }^{111} \operatorname{In}\left(\mathrm{L}_{2 / 3}\right)$ and the ( $\left.\mathrm{L}_{2 / 3}\right): f-\mathrm{MWNT}$ conjugates.

The SPECT/CT images at $30 \mathrm{~min}$ and $4 \mathrm{~h}$ post injection suggested that ${ }^{111} \operatorname{In}\left(\mathrm{L}_{2 / 3}\right)$ underwent fast renal excretion as indicated by the strong signals detected in bladder and/or kidney. Biliary excretion was also observed evidenced by the intense signals in gallbladder and gut lumen within the first $4 \mathrm{~h}$ after injection.

Unlike the free metal complexes, typical distribution patterns of ${ }^{111}$ In:f-MWNTs [26, 34] were obtained for the studied ${ }^{111} \operatorname{In}\left(\mathrm{L}_{2 / 3}\right): f$-MWNTs, indicating the successful conjugation of $\left(\mathrm{L}_{2 / 3}\right)$ with $f$-MWNTs successful in chelating ${ }^{111} \mathrm{In}$. The biodistribution profiles were essentially established at the early time point for all the conjugates. ${ }^{111} \operatorname{In}\left(\mathrm{L}_{2}\right)$ :ox-MWNTs showed accumulation in the order of lung $>$ liver=spleen while ${ }^{111} \operatorname{In}\left(\mathrm{L}_{2}\right)$ :oxMWNTs- $\mathrm{NH}_{3}{ }^{+}$displayed comparable levels of uptake in these three organs. Reduction in lung uptake was observed for both ${ }^{111} \operatorname{In}\left(\mathrm{L}_{2}\right)$ :f-MWNTs over time. In contrast to ${ }^{111} \operatorname{In}\left(\mathrm{L}_{2}\right): f-M W N T s$, most of ${ }^{111} \operatorname{In}\left(\mathrm{L}_{3}\right): f-$ MWNTs was detected in liver and, at a smaller extent, spleen (up to $24 \mathrm{~h}$ ). Some signals were detected in the bladder/kidney (30 min) and in the gut lumen $(4 \mathrm{~h})$ suggesting dissociation of ${ }^{111} \operatorname{In}\left(\mathrm{L}_{2 / 3}\right)$ from the conjugates.

SPECT/CT images focusing on the brain at the early time point $(30 \mathrm{~min})$ are shown in Fig. 5. Signals of ${ }^{111} \operatorname{In}\left(\mathrm{L}_{2 / 3}\right)$ were excluded from the brain cavity while some signals of ${ }^{111} \operatorname{In}\left(\mathrm{L}_{2 / 3}\right): f$-MWNTs can be seen inside and brain. ${ }^{111} \mathrm{In}\left(\mathrm{L}_{2 / 3}\right)$ :ox-MWNTs- $\mathrm{NH}_{3}{ }^{+}$showed higher brain accumulation than ${ }^{111} \operatorname{In}\left(\mathrm{L}_{2 / 3}\right)$ :ox-MWNTs with the highest observed for ${ }^{111} \operatorname{In}\left(\mathrm{L}_{2}\right)$ :ox-MWNTs$\mathrm{NH}_{3}{ }^{+}$.

\section{Quantitative assessments of organ uptake of $111 \ln \left(L_{2 / 3}\right)$ and $111 \ln \left(L_{2 / 3}\right): 0 x-M W N T s-N_{3}{ }^{+}$ following i.v. injection by $\mathbf{Y}$-scintigraphy}

Quantitative organ biodistribution and brain uptake was performed by $\gamma$-scintigraphy for amine modified derivatives as they showed higher brain uptake than the carboxylated derivatives; ${ }^{111} \operatorname{In}\left(\mathrm{L}_{2 / 3}\right)$ were used for comparison. 


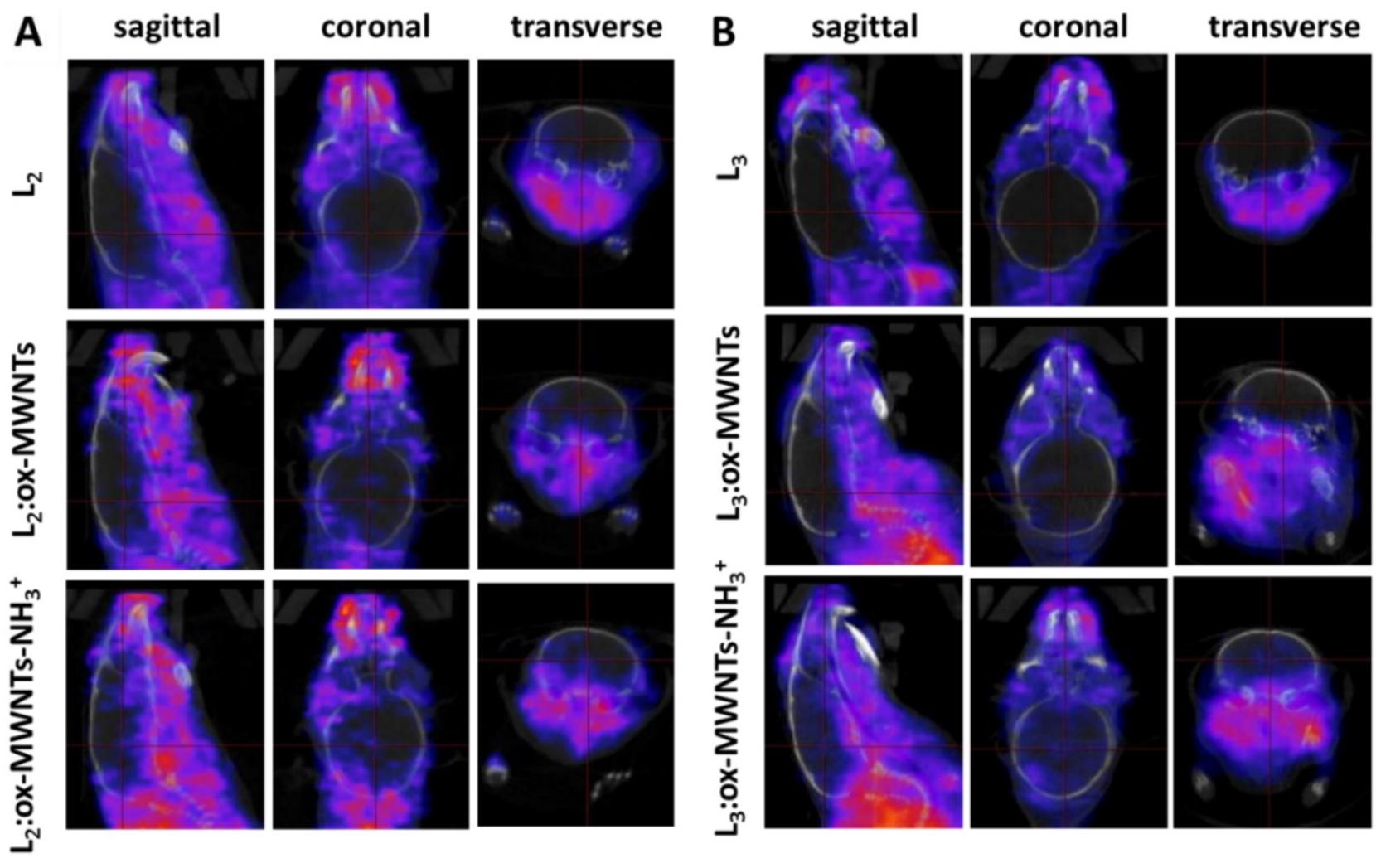

Figure 5. SPECT/CT images of 11 In-labelled $L_{2 / 3}$ and $L_{2 / 3}: f-M W N T s$ conjugates in mouse brain following i.v. injection. $C 57 B L / 6$ mice were i.v. injected with (A)

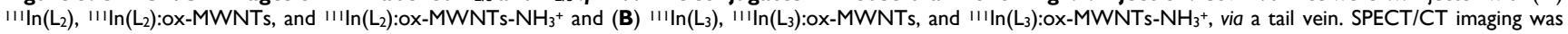
performed within 30 min post injection.

As revealed in Fig. 6A, significantly higher levels of ${ }^{111} \operatorname{In}\left(\mathrm{L}_{2 / 3}\right)$ were found in the blood 2 min after injection ( $44.0-49.1 \%$ ID) compared to MWNTs conjugates $(\sim 12.1-15.3 \%$ ID) $(p<0.001)$. The prolonged blood circulation time observed for ${ }^{111} \operatorname{In}\left(\mathrm{L}_{2 / 3}\right)$ was possibly due to binding to serum proteins. The short blood circulation times detected for f-MWNTs conjugates agreed with our previous studies with values ranging from 6 to $14 \%$ of ID at $2-5 \mathrm{~min}$ post-injection $[25,27]$.

The analysis of the biodistribution profile of conjugates/complexes (Fig. 6B) revealed that ${ }^{111} \mathrm{In}\left(\mathrm{L}_{2 / 3}\right)$ :ox-MWNTs- $\mathrm{NH}_{3}{ }^{+}$accumulated primarily in the liver, spleen and lungs $30 \mathrm{~min}$ after injection, with differences between the two conjugates: while similar levels were detected in the liver $(23.5-30.9 \%$ ID/g of tissue), preferential lung accumulation was found for ${ }^{111} \mathrm{In}\left(\mathrm{L}_{2}\right)$ : ox-MWNTs- $\mathrm{NH}_{3}{ }^{+}(32.6 \pm 5.8 \% \mathrm{ID} / \mathrm{g}$ of tissue $)$ than ${ }^{111} \operatorname{In}\left(\mathrm{L}_{3}\right):$ ox-MWNTs- $\mathrm{NH}_{3}{ }^{+}(12.7 \pm 2.3 \% \mathrm{ID} / \mathrm{g}$ of tissue) $(p<0.01)$. On the contrary, higher spleen uptake was found for ${ }^{111} \mathrm{In}\left(\mathrm{L}_{3}\right)$ :ox-MWNTs- $\mathrm{NH}_{3}{ }^{+}(51.6 \pm 12.9)$ than ${ }^{111} \operatorname{In}\left(\mathrm{L}_{2}\right)$ : ox-MWNTs- $\mathrm{NH}_{3}{ }^{+}(24.2 \pm 10.3 \% \mathrm{ID} / \mathrm{g})$ $(p<0.05)$. Uptake of $f-M W N T$ in RES organs was previously reported in our studies [25-27, 34]. Agreeing with SPECT/CT data, ${ }^{111} \operatorname{In}\left(\mathrm{L}_{2 / 3}\right)$ showed significantly higher levels in the kidneys ( 51.1 $74.9 \%)$ compared to the conjugates ( $6.1-16.3)$.
The preferential accumulation of $\mathrm{L}_{2}$ and $\mathrm{L}_{3}$ conjugates in the lung and spleen, respectively, could be due to difference in structure of possibly the final net charge of the conjugates. It has been shown in preclinical studies involving lipid-mediated delivery of siRNAs to dendritic cells that adjusting nanoparticle net charge to negative values can benefit spleen uptake, whereas positively-charged nanoparticles favour lung retention [36]. Although the physico-chemical, structural and biological properties of f-MWNTs and lipid nanoparticles are significantly different, this observation could help explain the differential uptake of ${ }^{111} \mathrm{In}\left(\mathrm{L}_{2 / 3}\right)$ :ox-MWNTs- $\mathrm{NH}_{3}{ }^{+}$by lungs and spleen. Since $\mathrm{L}_{2}$ and $\mathrm{L}_{3}$ are probably neutrally charged at physiological $\mathrm{pH}$, the determination of the net surface charge of ${ }^{111} \mathrm{In}\left(\mathrm{L}_{2 / 3}\right)$ :ox-MWNTs- $\mathrm{NH}_{3}{ }^{+}$complexes in the blood could is needed to help understand this observation.

Importantly, previous histological studies from our group using organ samples from mice injected intravenously with ox-MWNTs- $\mathrm{NH}_{3}{ }^{+}$showed no signs of tissue necrosis, fibrosis, or inflammation at different time points after administration $(1 \mathrm{~h}, 7$ days, 30 days) [33]. Moreover, in vivo degradation of CNTs has been demonstrated in different studies. Using TEM and Raman spectroscopy, our group found evidence of $\mathrm{MWNT}-\mathrm{NH}_{3}{ }^{+}$degradation in mouse 
brain 14 days after stereotactic injection, with partial degradation following internalization and intracellular localization within microglia starting as early as 2 days after injection [28]. Studies by Kagan and colleagues using TEM, Raman spectroscopy and photoacoustic imaging have also shown peroxynitrite-induced macrophage-mediated degradation of SWNTs in lung tissue following pharyngeal administration in mice [37]. Nevertheless, further studies need to provide qualitative and quantitative data regarding the formation of by-products induced by CNT degradation, aiming at its clinical application.

Fig. 6B revealed higher brain accumulation of ${ }^{111} \operatorname{In}\left(\mathrm{L}_{2}\right)$ :ox-MWNTs- $\mathrm{NH}_{3}{ }^{+}(1.16 \pm 0.23 \% \mathrm{ID} / \mathrm{g})$ than ${ }^{111} \mathrm{In}\left(\mathrm{L}_{3}\right):$ ox-MWNTs- $\mathrm{NH}_{3}{ }^{+} \quad(0.22 \pm 0.03 \quad \% \mathrm{ID} / \mathrm{g}$ $(\mathrm{p}<0.001)$ or ${ }^{111} \operatorname{In}\left(\mathrm{L}_{2 / 3}\right)(\sim 0.07-0.12 \% \operatorname{ID} / \mathrm{g})(\mathrm{p}<0.001)$ at $30 \mathrm{~min}$ post-injection. This value is superior to those reported for ${ }^{111}$ In-labelled $\mathrm{L}_{1}(0.36$ and $0.5 \% \mathrm{ID} / \mathrm{g}$ tissue in cortex and cerebellum at $30 \mathrm{~min}$ ) [11], $\mathrm{PiB}$ [38] or A $\beta$-targeting ApoE-conjugated phosphatidic acid-encapsulating liposomes (a maximum of $0.3 \%$ ID/g of brain achieved at $24 \mathrm{~h}$ after injection) [39].

\section{Brain distribution profile of $111 \ln \left(L_{2 / 3}\right)$ and $111 \ln \left(\mathrm{L}_{2 / 3}\right)$ :ox-MWNTs- $\mathrm{NH}_{3}{ }^{+}$following i.v. injection by $\mathrm{Y}$-scintigraphy}

To determine the amount of injected conjugates/ligands that reach the different brain tissues, endothelial cells (capillaries) and parenchyma were separated using capillary depletion (Fig. 7A). Higher levels of ${ }^{111} \mathrm{In}\left(\mathrm{L}_{2}\right)$ :ox-MWNTs- $\mathrm{NH}_{3}{ }^{+}$were detected in both parenchyma and capillary fractions $(\sim 0.15$ and $0.26 \%$ ID/fraction, respectively) than ${ }^{111} \operatorname{In}\left(\mathrm{L}_{3}\right)$ :ox-MWNTs- $\mathrm{NH}_{3}{ }^{+} \quad(\sim 0.04$ and $\quad 0.09 \% \mathrm{ID} /$ fraction, $\mathrm{p}<0.001$ and 0.01 ). While a larger proportion of ${ }^{111} \operatorname{In}\left(\mathrm{L}_{2}\right)$ :ox-MWNTs- $\mathrm{NH}_{3}{ }^{+}$was found in capillaries $(\sim 0.26 \% \mathrm{ID})$, the difference to the parenchyma fraction was not statistically significant $(\sim 0.15 \%$ ID; $p>0.05$ using unpaired t-test with Welch's correction). Values detected for ${ }^{111} \operatorname{In}\left(\mathrm{L}_{2 / 3}\right)$ were all below 0.05 $\% \mathrm{ID} /$ fraction.

A better measure for the extent of brain penetration - i.e. the translocation from blood to brain tissue across the $\mathrm{BBB}$ - is given by the brain parenchyma to blood ratio ( $\mathrm{P} / \mathrm{B}$ ratio) [40]. In this regard, the highest $\mathrm{P} / \mathrm{B}$ ratio was obtained for ${ }^{111} \operatorname{In}\left(\mathrm{L}_{2}\right)$ :ox-MWNTs- $\mathrm{NH}_{3}{ }^{+} \quad(\sim 0.074)$ compared to ${ }^{111} \operatorname{In}\left(\mathrm{L}_{3}\right)$ :ox-MWNTs- $\mathrm{NH}_{3}{ }^{+}(\sim 0.04, \mathrm{p}<0.01)$ or to the residual values obtained for ${ }^{111} \operatorname{In}\left(\mathrm{L}_{2 / 3}\right)$ (Fig. 7 B) .

Overall, these results indicate that conjugation of $\mathrm{L}_{2}$ to ox-MWNTs- $\mathrm{NH}_{3}{ }^{+}$significantly improved its brain accumulation while a small and non-significant improvement was obtained for $\mathrm{L}_{3}$. The whole-brain uptake values $(1.16 \% \mathrm{ID} / \mathrm{g}$ of tissue) and $\mathrm{P} / \mathrm{B}$ ratio $(\sim 074)$ obtained in this study were lower than those obtained in previous studies from our group (1.5 to $3 \% \mathrm{ID} / \mathrm{g}$ of brain; 0.2 to $0.7 \mathrm{P} / \mathrm{B}$ ratio) $[26,39]$ and those of known CNS drugs (including morphine) [41] $(\mathrm{P} / \mathrm{B}$ ratios $>0.5)$. They are however higher than those reported for other types of brain-targeting nanoparticles (0.3 to $0.5 \%$ ID/g of brain) [31, 42-44] and several clinical CNS drugs ( $0.2 \%$ of administered dosage) [45-47]. Future conjugation to brain-targeting peptides (e.g. angiopep-2, a ligand of low-density lipoprotein receptor-related protein 1 (LPR-1)) may improve brain targeting even further [26].
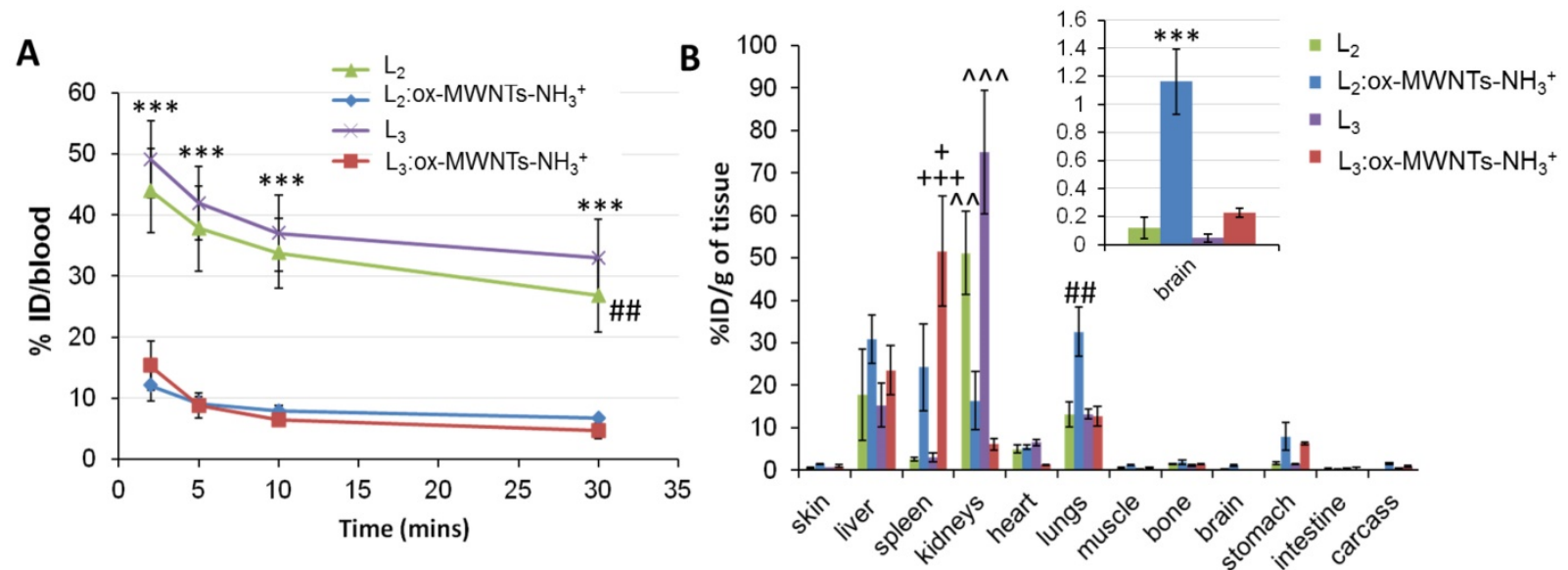

Figure 6. Blood and organ biodistribution profiles of 11 In-labelled $L_{2}$ and $L_{3}$, in its free form or conjugated to ox-MWNTs-NH ${ }_{3}{ }^{+}$, following systemic administration in healthy C57BL/6 mice. Mice were injected (via tail vein) with ${ }^{\prime \prime}$ In-labelled $\mathrm{L}_{2 / 3}$ or ${ }^{\prime \prime \prime} \ln \left(\mathrm{L}_{2 / 3}\right): \mathrm{ox}-\mathrm{MWNTs}-\mathrm{NH} \mathrm{H}_{3}{ }^{+}(50 \mu \mathrm{Hg}, 0.5 \mathrm{MBq})$. Blood was sampled at 2 , 5,10 and 30 min post-injection, followed by whole-body perfusion with heparinised saline. All major organs were immediately harvested and the radioactivity of (A) blood and (B) organs was measured by gamma counting. The Results are presented as (A) \% injected dose per blood and (B) \% injected dose per gram of tissue (inset: magnification of brain distribution). Statistical analysis of the results (mean \pm SD, $n=3$;) was performed using One-way ANOVA with Tukey's posthoc test. (A) **** $\mathrm{P}<0.001$ compared to animals

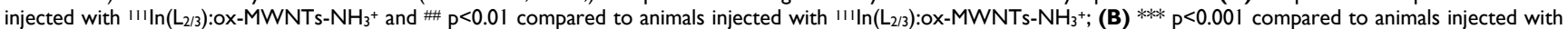

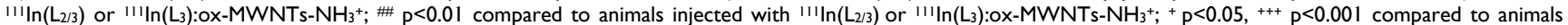
injected with $111 \ln \left(\mathrm{L}_{2}\right)$ :ox-MWNTs- $\mathrm{NH}_{3}{ }^{+}$or $\mathrm{L}_{2 / 3}$, respectively; $\wedge \wedge \mathrm{p}<0.01, \wedge \wedge \wedge \quad \mathrm{p}<0.001$ compared to animals injected with $111 \mathrm{ln}\left(\mathrm{L}_{2}\right)$ : $0 x-\mathrm{MWNTs}-\mathrm{NH}_{3}{ }^{+}$or $I I I \ln \left(\mathrm{L}_{3}\right)$ :ox-MWNTs-NH${ }_{3}^{+}$. 


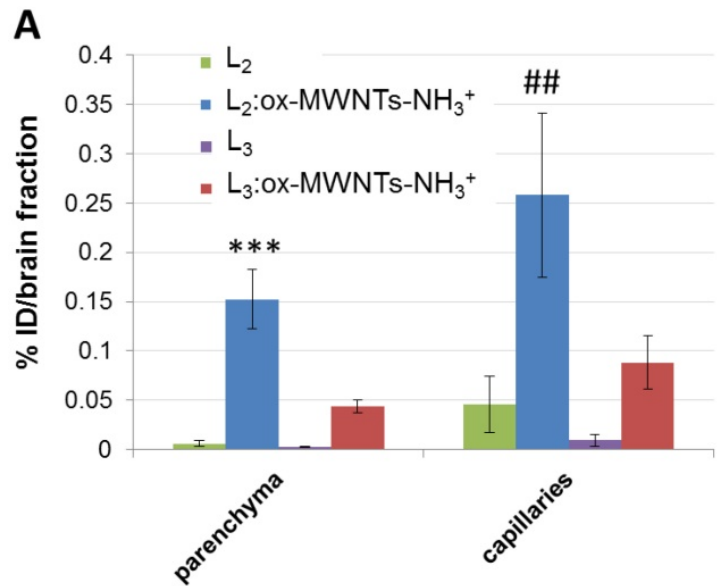

B

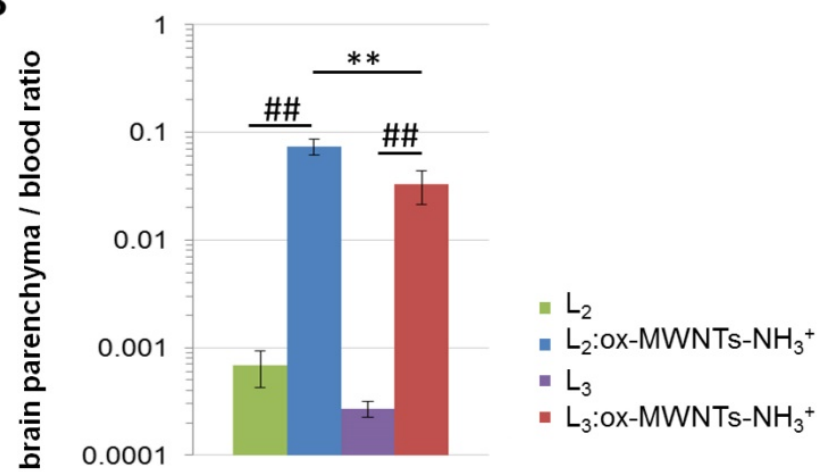

Figure 7. Brain distribution profile of 111 In-labelled $\mathrm{L}_{2}$ and $\mathrm{L}_{3}$, in its free form or conjugated to ox-MWNTs-NH ${ }_{3}^{+}$, following systemic administration in

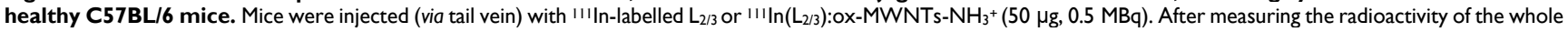
organs, brain tissues were processed to separate brain parenchyma from capillaries (via capillary depletion) and the radioactivity of each fraction was measured by gamma counting (A), with the data presented as \% ID per total brain parenchyma or capillaries. (B) For brain parenchyma to blood ratio calculation, the weight of parenchyma was considered as the weight of the whole brain. Inset: magnification of brain parenchyma/blood ratio for $L_{2}$ and $L_{3}$. Statistical analysis of the results (mean $\pm S D, n=3$;) was

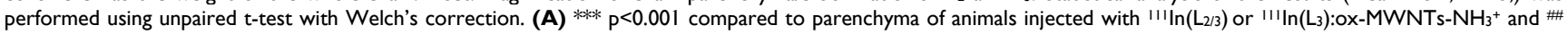

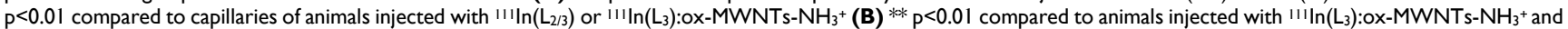
\#\# $\mathrm{p}<0.01$ compared to animals injected with $111 \ln \left(\mathrm{L}_{2 / 3}\right)$.

\section{Conclusion}

This study provides evidence of the potential of functionalised MWNTs to be used as carriers for brain delivery of drugs/compounds that do not significantly cross the BBB, with possible clinical application in the diagnostic and treatment of neurological disorders. Future studies will aim at improving brain uptake of $\mathrm{Gd}\left(\mathrm{L}_{2}\right)$ :MWNT conjugates via receptor-mediated transcytosis (by conjugation to angiopep1) and further testing the imaging and therapeutic ability in a relevant AD mouse model.

\section{Supplementary Material}

Supplementary figures and tables.

http://www.ntno.org/v02p0168s1.pdf

\section{Acknowledgements}

The authors would like to thank Andy Cakebread (King's College London) for the assistance with the ICP-MS measurements and Zoltan Garda and Alexandre C. Oliveira (CBM Orléans) for the $\log P$ measurements. This work was supported by funds from the Wellcome Trust [WT103913], Biotechnology and Biological Sciences Research Council [BB/ J008656/1], Worldwide Cancer Research [12-1054], Brain Tumour Charity [GN-000398], the Ligue contre le Cancer Grand-Ouest [comittees 17 and 45] and the Agence Nationale de la Recherche, France [ANR-16-CE18-0022-01] and COST Action TD1004. P. M. Costa is a Sir Henry Wellcome Post-doctoral fellow.

\section{Competing Interests}

The authors have declared that no competing interest exists.

\section{References}

1. Serrano-Pozo A, Frosch MP, Masliah E, Hyman BT. Neuropathological alterations in Alzheimer disease. Cold Spring Harbor Perspectives in Medicine. 2011; 1: a006189.

2. Heneka MT, Golenbock DT, Latz E. Innate immunity in Alzheimer's disease. Nature Immunology. 2015; 16: 229-36.

3. Barage SH, Sonawane KD. Amyloid cascade hypothesis: Pathogenesis and therapeutic strategies in Alzheimer's disease. Neuropeptides. 2015; 52: 1-18.

4. Dubois B, Picard G, Sarazin M. Early detection of Alzheimer's disease: new diagnostic criteria. Dialogues in Clinical Neuroscience. 2009; 11: 135-9.

5. Forlenza OV, Radanovic M, Talib LL, Aprahamian I, Diniz BS, Zetterberg H, et al. Cerebrospinal fluid biomarkers in Alzheimer's disease: diagnostic accuracy and prediction of dementia. Alzheimer's \& Dementia. 2015; 1: 455-63.

6. Ono M, Wilson A, Nobrega J, Westaway D, Verhoeff P, Zhuang ZP, et al. 11C-labeled stilbene derivatives as Abeta-aggregate-specific PET imaging agents for Alzheimer's disease. Nuclear Medicine and Biology. 2003; 30: 565-71.

7. Mathis CA, Bacskai BJ, Kajdasz ST, McLellan ME, Frosch MP, Hyman BT, et al. A lipophilic thioflavin-T derivative for positron emission tomography (PET) imaging of amyloid in brain. Bioorganic \& Medicinal Chemistry Letters. 2002; 12: $295-8$.

8. The chemistry of contrast agents in medical magnetic resonance imaging. 2nd ed: John Wiley \& Sons, Ltd; 2013.

9. Yang L, Chen Q, Liu Y, Zhang J, Sun D, Zhou Y, et al. Se/Ru nanoparticles as inhibitors of metal-induced AB aggregation in Alzheimer's disease. Journal of Materials Chemistry B. 2014; 2: 1977-1987.

10. Yin T, Yang L, Liu Y, Zhou X, Sun J, Lin J. Sialic acid (SA)-modified selenium nanoparticles coated with a high blood-brain barrier permeability peptide-B6 peptide for potential use in Alzheimer's disease. Acta Biomaterialia. 2015; 25: 172-183.

11. Martins AF, Morfin JF, Kubickova A, Kubicek V, Buron F, Suzenet F, et al. PiB-Conjugated, Metal-Based Imaging Probes: Multimodal Approaches for the Visualization of beta-Amyloid Plaques. ACS Medicinal Chemistry Letters. 2013; 4: 436-40.

12. Martins AF, Morfin JF, Geraldes CF, Toth E. Gd(3+) complexes conjugated to Pittsburgh compound B: potential MRI markers of beta-amyloid plaques. Journal of Biological Inorganic Chemistry. 2014; 19: 281-95.

13. Bacskai BJ, Hickey GA, Skoch J, Kajdasz ST, Wang Y, Huang GF, et al. Four-dimensional multiphoton imaging of brain entry, amyloid binding, and clearance of an amyloid-beta ligand in transgenic mice. Proceedings of the National Academy of Sciences of the United States of America. 2003; 100: 12462-7. 
14. Nau R, Sorgel F, Eiffert H. Penetration of drugs through the blood-cerebrospinal fluid/blood-brain barrier for treatment of central nervous system infections. Clinical Microbiology Reviews. 2010; 23: 858-83.

15. Pajouhesh H, Lenz GR. Medicinal chemical properties of successful central nervous system drugs. NeuroRx. 2005; 2: 541-53.

16. Pardridge WM. Targeting neurotherapeutic agents through the blood-brain barrier. Archives of Neurology. 2002; 59: 35-40.

17. Lay CL, Liu HQ, Tan HR, Liu Y. Delivery of paclitaxel by physically loading onto poly(ethylene glycol) (PEG)-graft-carbon nanotubes for potent cancer therapeutics. Nanotechnology. 2010; 21: 065101.

18. Zhu X, Xie Y, Zhang Y, Huang H, Huang S, Hou L, et al. Thermo-sensitive liposomes loaded with doxorubicin and lysine modified single-walled carbon nanotubes as tumor-targeting drug delivery system. Journal of Biomaterials Applications. 2014; 29: 769-79.

19. Pantarotto D, Singh R, McCarthy D, Erhardt M, Briand JP, Prato M, et al. Functionalized carbon nanotubes for plasmid DNA gene delivery. Angewandte Chemie. 2004; 43: 5242-6.

20. Vardharajula S, Ali SZ, Tiwari PM, Eroglu E, Vig K, Dennis VA, et al. Functionalized carbon nanotubes: biomedical applications. International Journal of Nanomedicine. 2012; 7: 5361-74.

21. Dumortier H, Lacotte S, Pastorin G, Marega R, Wu W, Bonifazi D, et al. Functionalized carbon nanotubes are non-cytotoxic and preserve the functionality of primary immune cells. Nano Letters. 2006; 6: 1522-8.

22. Farvadi F, Tamaddon A, Sobhani Z, Abolmaali SS. Polyionic complex of single-walled carbon nanotubes and PEG-grafted-hyperbranched polyethyleneimine (PEG-PEI-SWNT) for an improved doxorubicin loading and delivery: development and in vitro characterization. Artificial Cells, Nanomedicine, and Biotechnology. 2016: 1-9.

23. Wolski P, Nieszporek K, Panczyk T. Pegylated and folic acid functionalized carbon nanotubes as $\mathrm{pH}$ controlled carriers of doxorubicin. Molecular dynamics analysis of the stability and drug release mechanism. Physical Chemistry Chemical Physics. 2017; 19: 9300-12.

24. Costa PM, Bourgognon M, Wang JT, Al-Jamal KT. Functionalised carbon nanotubes: From intracellular uptake and cell-related toxicity to systemic brain delivery. Journal of Controlled Release. 2016; 241: 200-19.

25. Kafa H, Wang JT, Rubio N, Venner K, Anderson G, Pach E, et al. The interaction of carbon nanotubes with an in vitro blood-brain barrier model and mouse brain in vivo. Biomaterials. 2015; 53: 437-52.

26. Kafa H, Wang JT, Rubio N, Klippstein R, Costa PM, Hassan HA, et al. Translocation of LRP1 targeted carbon nanotubes of different diameters across the blood-brain barrier in vitro and in vivo. Journal of Controlled Release. 2016; 225: 217-29.

27. Wang JT, Rubio N, Kafa H, Venturelli E, Fabbro C, Menard-Moyon C, et al. Kinetics of functionalised carbon nanotube distribution in mouse brain after systemic injection: Spatial to ultra-structural analyses. Journal of Controlled Release. 2016; 224: 22-32

28. Nunes A, Bussy C, Gherardini L, Meneghetti M, Herrero MA, Bianco A, et al. In vivo degradation of functionalized carbon nanotubes after stereotactic administration in the brain cortex. Nanomedicine. 2012; 7: 1485-94.

29. Hassan HA, Smyth L, Rubio N, Ratnasothy K, Wang JT, Bansal SS, et al. Carbon nanotubes' surface chemistry determines their potency as vaccine nanocarriers in vitro and in vivo. Journal of Controlled Release. 2016; 225: 205-16.

30. Bai J, Wang JT, Rubio N, Protti A, Heidari H, Elgogary R, et al. Triple-Modal Imaging of Magnetically-Targeted Nanocapsules in Solid Tumours In Vivo. Theranostics. 2016; 6: 342-56.

31. van Rooy I, Mastrobattista E, Storm G, Hennink WE, Schiffelers RM. Comparison of five different targeting ligands to enhance accumulation of liposomes into the brain. Journal of Controlled Release. 2011; 150: 30-6.

32. Chang X, Henderson WM, Bouchard DC. Multiwalled carbon nanotube dispersion methods affect their aggregation, deposition, and biomarker response. Environmental Science \& Technology. 2015; 49: 6645-53.

33. Al-Jamal KT, Nunes A, Methven L, Ali-Boucetta H, Li S, Toma FM, et al. Degree of chemical functionalization of carbon nanotubes determines tissue biodistribution and excretion profile. Angewandte Chemie International Edition. 2012; 51: 6389-6393.

34. Wang JT, Fabbro C, Venturelli E, Menard-Moyon C, Chaloin O, Da Ros T, et al. The relationship between the diameter of chemically-functionalized multi-walled carbon nanotubes and their organ biodistribution profiles in vivo. Biomaterials. 2014; 35: 9517-28.

35. Kaiser E, Colescott RL, Bossinger CD, Cook PI. Color test for detection of free terminal amino groups in the solid-phase synthesis of peptides. Analytical Biochemistry. 1970; 34: 595-8.

36. Kranz LM, Diken M, Haas H, Kreiter S, Loquai C, Reuter KC, et al. Systemic RNA delivery to dendritic cells exploits antiviral defence for cancer immunotherapy. Nature. 2016; 534: 396-401.

37. Kagan VE, Kapralov AA, St Croix CM, Watkins SC, Kisin ER, Kotchev GP, et al. Lung macrophages "digest" carbon nanotubes using superoxide/peroxynitrite oxidative pathway. ACS Nano. 2014; 8: 5610-21.

38. Mathis CA, Wang Y, Holt DP, Huang GF, Debnath ML, Klunk WE. Synthesis and evaluation of 11C-labeled 6-substituted 2-arylbenzothiazoles as amyloid imaging agents. Journal of Medicinal Chemistry. 2003; 46: 2740-54.

39. Bana L, Minniti S, Salvati E, Sesana S, Zambelli V, Cagnotto A, et al. Liposomes bi-functionalized with phosphatidic acid and an ApoE-derived peptide affect Abeta aggregation features and cross the blood-brain-barrier: implications for therapy of Alzheimer disease Nanomedicine. 2014; 10: 1583-90

40. van Rooy I, Cakir-Tascioglu S, Hennink WE, Storm G, Schiffelers RM, Mastrobattista E. In vivo methods to study uptake of nanoparticles into the brain. Pharmaceutical Research. 2011; 28: 456-71.

41. Hammarlund-Udenaes M, Friden M, Syvanen S, Gupta A. On the rate and extent of drug delivery to the brain. Pharmaceutical Research. 2008; 25: 1737-50.

42. Ke W, Shao K, Huang R, Han L, Liu Y, Li J, et al. Gene delivery targeted to the brain using an angiopep-conjugated polyethyleneglycol-modified polyamidoamine dendrimer. Biomaterials. 2009; 30: 6976-85.

43. Schnyder A, Krahenbuhl S, Drewe J, Huwyler J. Targeting of daunomycin using biotinylated immunoliposomes: pharmacokinetics, tissue distribution and in vitro pharmacological effects. Journal of Drug Targeting. 2005; 13: 325-35.

44. Xie Y, Ye L, Zhang X, Cui W, Lou J, Nagai T, et al. Transport of nerve growth factor encapsulated into liposomes across the blood-brain barrier: in vitro and in vivo studies. Journal of Controlled Release. 2005; 105: 106-19.

45. Abbott NJ. Inflammatory mediators and modulation of blood-brain barrier permeability. Cellular and Molecular Neurobiology. 2000; 20: 131-47.

46. Habgood MD, Begley DJ, Abbott NJ. Determinants of passive drug entry into the central nervous system. Cellular and Molecular Neurobiology. 2000; 20: 231-53.

47. Summerfield SG, Zhang Y, Liu H. Examining the uptake of central nervous system drugs and candidates across the blood-brain barrier. The Journal of Pharmacology and Experimental Therapeutics. 2016; 358: 294-305. 